\title{
Pay Gap among Executives and Firm Value
}

\author{
Shage Zhang $^{1}$
}

September 2012

We study the relationship between pay gaps among top executives and firm value using the insights from a principal-agent framework. Large pay gaps on one hand reduce managerial shirking by imposing a large promotion incentive, and on the other hand they can induce counter-productive rivalries. Hence, both the pay gap level and its impact on firm value are jointly determined by the firm's optimizing pay gap so that the marginal benefit of reducing managerial moral hazard is balanced against the expected marginal costs of uncooperative manager behavior. We find that complex firms tend to have larger pay gaps, and their firm values increase with the pay gap level. On the other hand, R\&D intensive firms tend to have lower pay gaps, and the effect of pay gaps on their firm value is much lower and can even become negative. We also find a substitution effect between pay gaps and other mechanisms used to control moral hazard problems. When strong corporate governance and high equity delta reduce managerial moral hazard, the marginal benefit of having a large pay gap declines significantly. Using the 2003 dividend tax cut as a quasi-natural experiment that exogenously increases effective managerial ownership, we find additional evidence reinforcing our primary findings, which provides further support for our main hypothesis.

JEL classification: G30, G35, J33

Keywords: Pay gap, Compensation, Firm performance, Moral hazard, Agency problems, Sabotage, Equity delta

\footnotetext{
"I thank Ronald Masulis, Craig Lewis, Alexei Ovtchinnikov, David Parsley, Tong Li, Hans Stoll, and Jacob Sagi for their comments.

${ }^{1}$ Department of Business Administration, Trinity University, San Antonio, TX, Tel: 210-999-7083, Email: szhang@trinity.edu
} 


\section{Introduction}

The compensation of corporate CEOs has been studied extensively in the past two decades, but few studies have explored the compensation arrangements of other top executives or the pay distribution of the corporation's top executive team. ${ }^{2}$ Bebchuk, Cremers and Peyer (2011) study the pay gap from corporate governance perspective, and they view the slice of CEO pay over the aggregate compensation of the top five executives as a manifestation of CEO power and document a negative relation between pay gap and firm performance. Aggarwal, Fu and Pan (2010) empirically test the bottom-up incentives (referred as internal governance) modeled in Acharya, Myers and Rajan (2010), and they find a hump-shape relation between pay gap and firm investment. ${ }^{3}$ Kale, Reis, and Venkateswaran (2009) view the pay gap as an incentive mechanism to solve the moral hazard problem as modeled in Lazear and Rosen (1981): large pay gap motivates non-CEO executives to work hard for promotion and reduces managerial shirking. They find that firm value increases in pay gap. Thus, the effects of pay gap on firm value are currently in dispute.

In this study, we consider a neglected perspective in empirical studies - the collaboration among executives and the efficiency of management team production. Lazear (1989) points out that large pay gaps potentially undermine collaboration among senior executives and leads to value-destroying office politics and even conscious sabotage. More specifically, non-CEO executives may have incentives to devote effort in damaging their competitors' performance in order to inflate their own chances of being promoted to the CEO position, when the pay increase upon promotion is relatively high. Given the fact that the executive responsibilities are invariably shared and firm decisions embody the mutual agreement of the senior executive group, a properly designed incentive mechanism should minimize managerial moral hazard, while maximizing executive cooperation, so as to attain high overall management team productivity.

\footnotetext{
${ }^{2}$ Such studies include but not limit to Aggarwal and Samwick (2003), Kale, Reis, and Venkateswaran (2009), Bebchuk, Cremers and Peyer (forthcoming), Aggarwal, Fu, and Pan (2010), Chen, Huang, and Wei (2011), Kini and Williams (forthcoming).

${ }^{3}$ The intuition is that when the CEO is paid less than managers, managers have little incentive to learn or exert effort and CEO has little incentive to invest for the long-run. On the other hand, when the CEO is paid quite high relative to the managers and the CEO is dominant, then CEO then again has little incentive to invest for the longterm. They measure the pay gap as the difference in abnormal compensation between the CEO and non-CEO executives.
} 
We examine the pay gap through the lens of a simple principal-agent framework. Modifying the Lazear (1989) model, we add governance mechanisms that mitigate the moral hazard problem, i.e. equity-based executive compensation. The principal in the corporate context is its shareholders and the agents are the CEO and two senior executives who are competing to be the next CEO. The pay gap derived from the model is jointly determined by the expected marginal benefit of improving managerial incentives by linking their chances of promotion to the effort they put in and the expected marginal cost of inducing counterproductive rivalries (sabotage) among senior executives. Sabotage refers to the general behavior that reduces coworker productivity while not improving one's own productivity. This stylized model also predicts that the pay gap level depends negatively on agents' equity deltas: the marginal benefit of having a large pay gap to lower moral hazard problems (including shirking) is reduced when other governance mechanisms exist to align manager and shareholder interests. In other words, equity-based incentives and corporate governance work as substitutes for a large pay gap. We then examine the relationship between pay gap and firm value. Our model clearly indicates that the effect of pay gap on firm output is a function of the parameters that capture key firm and executive characteristics. More specifically, the effect of pay gap on firm output is larger when the marginal benefit of reducing manager moral hazard problems is large, such as when managers have higher marginal productivity of effort. On the other hand, the effect of pay gap on firm output is reduced by the damage caused by counter-productive executive rivalries. The effect of pay gap on firm output is also found to fall when a firm's equity returns is riskier.

Using data on executive compensation for US public firms from 1996 to $2005,{ }^{4}$ we find strong support for the predictions derived from our model. The pay gap is larger when managerial moral hazard problems are more severe, and the pay gap is smaller when the expected cost of counter-productive executive rivalries is more serious. Examining the relationship between pay gap and firm performance, we find that the effect of pay gap on firm performance is significantly positive when the firm has greater manager-shareholder agency conflicts, creating a large managerial moral hazard problem. On the other hand, the effect of pay gap on firm performance is greatly diminished and can even be negative, when managerial shirking concerns are small, while improving collaboration and management team productivity is

\footnotetext{
${ }^{4}$ The public firms in our data are S\&P 500 large cap firms, S\&P 400 mid cap firms, and S\&P 600 small cap firms, that are reported in the Execucomp database.
} 
a first order of magnitude issue. These relationships provide evidence that the pay gap's impact on firm performance is not uniform across all firms. Instead, this relationship is largely conditional on firm characteristics.

We measure the pay gap among top executives as the logarithm of dollar difference between CEO's total compensation and the median total compensation of non-CEO executives that are reported in a firm's proxy statement. We evaluate firm value by looking at its industryadjusted Q, both in the immediate future (a year ahead) and longer term (three years ahead). Examining the univariate statistics on the pay gap, we document several noteworthy findings. First, substantial cross-sectional heterogeneity exists in firm pay gaps, which is highlighted by a bottom quartile pay gap of $\$ 542,423$, compare to that in the top quartile of $\$ 3,427,720 .^{5}$ The pay gap rises over our sample period, with the median pay gap rising from \$935,530 in 1996 to $\$ 1,948,430$ in 2005. Alternatively, we use the CPS (CEO pay slice constructed by Bebchuk et al 2011) to measure pay gap. It is measured by the ratio of the CEO total compensation over the aggregate compensation of the top five executives. We also find an upward trend over time using this measure.

Second, pay gap is highly firm specific, with firm fixed effects explaining more than half of the cross-sectional variation. Pay gap is also strongly correlated with firm level characteristics. Large firms have significantly larger pay gap than otherwise similar firms. This is consistent with several model predictions. Large firms tend to be more difficult to monitor and can have more severe moral hazard problems, which calls for a higher pay gap to provide additional incentives. Moreover, marginal productivity of executive effort increases with firm size and complexity (i.e. Rosen 1981, Rosen 1982, Gabaix and Landier 2008), and our model predicts a positive relation between marginal productivity of executive effort and pay gap. We also find that pay gap rises as firms become risker, which is consistent with the idea that high risk firms are more difficult to monitor and hence face larger managerial moral hazard problems. On the other hand, pay gap declines as managerial moral hazard becomes less of a concern. For example, the pay gap is lower, when either firm corporate governance is strong or non-CEO top executive financial interests are better aligned with shareholders through a higher equity delta.

\footnotetext{
${ }^{5}$ Our pay gap distribution is similar, though slightly higher than that reported in Kale et al (2009), probably because our sample period is several years later than theirs. Our pay gap distribution appears to be same as Kale et al (2009) if we use their sample period.
} 
One of our hypotheses is that pay gap should be smaller when team production is critical to firm performance and when reducing counter-productive sabotage is a top priority. Siegel and Hambrick (2005) argue that top management collaboration is particularly important in technology-intensive firms, because of the substantial amount of information processing required and the need for frequent reassessments and adjustments in corporate strategies in the face of a rapid changing marketplace. ${ }^{6}$ We find that pay gap decreases with R\&D expenditures only when overall firm corporate governance is strong. When both managerial moral hazard and expected costs of competing manager sabotage are of major concern, a higher pay gap can be expected.

The third set of findings uncovers a relationship between pay gap and firm performance. The effect of pay gap on industry adjusted Tobin's Q averaged over the full sample is negative, but it is not statistically significant. In contrast to Aggarwal et al (2010), we do not find a humpshape relation using our pay gap measure. Neither does the effect of the pay gap-firm performance relationship depend on whether the large pay gap is due to high CEO compensation or low non-CEO executive compensation. In fact, we find that the pay gap-firm performance relationship is conditional on firm characteristics. The effect of pay gap on firm performance is positive and significant when monitoring costs are higher and managerial moral hazard is potentially more serious. For instance, the pay gap increases industry-adjusted Q significantly in large, complex firms, suggesting that such firms benefit more from having a larger pay gap. On the other hand, the marginal effect of pay gap on industry-adjusted Q declines and even becomes negative, as the level of managerial moral hazard falls. We find that pay gap has a significant negative correlation with firm performance in firms with strong corporate governance and a higher median non-CEO executive equity delta.

The relation between pay gap and firm performance also depends on how harmful employee sabotage is likely to be for firm performance. Our model predicts a low pay gap level and a low pay gap-firm performance relationship when team production is important and the expected cost of employee sabotage is large. We find that the coefficient on pay gap significantly

\footnotetext{
${ }^{6}$ This is a long stream of research and field studies in the management literature that looks at the environmental uncertainty and the degree of task interdependence, i.e. Thompson (1967), Galbraith (1973), Eisenhardt and Bourgeois (1988), Hambrick (1994) and etc. Siegel and Hambrick (2005) argue that among various forms of environmental uncertainty, R\&D intensity has the most pronounced effect on top management interdependence and collaboration, because first high R\&D intensive firms have large information processing requirements and second, innovations requires frequent negotiations and mutual adjustments.
} 
falls with firm technology-intensity, measured by R\&D expenses over total assets. We also find that the marginal effect of pay gap on industry-adjusted Q declines with firm risk, measured by volatility of stock returns, with an effect that is statistically significant at 1 percent level. This result complements the findings in Bloom and Michel (2002), who document that a large pay gap is associated with higher management turnover and shorter manager tenure and that this impact is exacerbated under more volatile operating conditions.

We use a quasi-natural experiment as our first approach to testing causality between pay gap and firm performance. The exogenous event we use as a quasi-natural experiment is the Bush Administration's 2003 Dividend Tax Cut. Chetty and Saez (2010) and Chetty and Saez (2005) theoretically and empirically show that dividend tax cut increases managers' after-tax wealth obtained from their equity holdings and hence effectively it increases the sensitivity of managerial wealth to firm value. This exogenous tax reform legislation results in improved alignment of manager interests with shareholders and reduces the managerial moral hazard problem. Consequently, the benefit of having a large pay gap in order to reduce the managerial moral hazard problem becomes less attractive. Therefore, we expect firms to reduce their pay gaps following the dividend tax cut in 2003, and the effect of pay gap level on firm value should also decrease after the tax cut. Indeed, we find that on average the pay gap declines significantly after the tax reform, controlling for other firm characteristics and a time trend. The magnitude of the pay gap drop is especially large for firms having high managerial ownership and paying out dividends regularly prior to the tax reform. Furthermore, we find the pay gap effect on firm value also falls after 2003 and the reduction is especially large for riskier and more R\&D intensive firms.

We also use a conventional IV-GMM approach to address potential endogeneity to further establish the causality of the pay gap-firm performance relationship. The exogenous instrumental variables for the pay gap are the industry's median pay gap level and the number of internal CEO successions by industry firms over the prior year. A firm's pay gap is highly correlated with industry pay gap since many firms tend to benchmark to industry peers in setting executive compensation. Furthermore, industry trends concerning hiring internal CEO candidates can significantly influence CEO succession decisions of other firms within the industry, and hence affect a firm's pay gap level. However, economically, there is no clear reason to expect 
these two industry specific variables to be directly related to an individual firm's industryadjusted Q. Formal statistical tests, including Hansen's J statistic and the Cragg-Donald Wald test, indicate that the two instrumental variables both meet the exclusion and relevance requirements for statistically valid IVs. Importantly, we find that our main findings regarding the relationship between pay gap and firm value continue to hold under the IV-GMM specifications.

Our paper is organized as follows. We present a simple model in Section 2 to motivate our empirical analysis. The data and sample construction are presented in section 3 . We report our primary empirical evidence in section 4. The quasi-natural experiment using 2003 tax cut is presented in section 5. We report our robustness tests in section 6 and conclude in section 7 .

\section{Model}

We adopt a simple model to illustrate how the choice of pay gap level reflects a tradeoff between the benefit of reducing managerial moral hazard and the expected cost of inducing lower level employee sabotage. Our model is similar to the framework in Lazear (1989), with our primary innovation being the inclusion of other incentive mechanisms to help align manager interests with those of shareholders. We emphasize the purpose of this model is purely to illustrate the relationship that inspires the later empirical tests, rather than to identify a specific structural equation system.

Consider two agents $j$ and $k$ who are competing to become the next CEO. The agent's productivity $q(\mu, \theta)$ is a positive function of his/her own effort $\mu$, and is a negative function of the rival's sabotage activity $\theta$. The agent also bears a cost $c(\mu, \theta)$, which is a positive function of the agent's individual effort to improve productivity and to sabotage the rival. The firm's output $Q$ depends on the collective effort and sabotage levels of the two agents:

$$
\begin{aligned}
& Q=q_{j}+q_{k} \\
& q_{j}=\alpha \mu_{j}-\beta \theta_{k}+\varepsilon_{j} \\
& q_{k}=\alpha \mu_{k}-\beta \theta_{j}+\varepsilon_{k} \\
& c_{j}=A \mu_{j}^{2}+B \theta_{j}^{2} \\
& c_{k}=A \mu_{k}^{2}+B \theta_{k}^{2}
\end{aligned}
$$


The parameter $\alpha$ reflects the agent's marginal productivity of effort, which may be a function of firm risk $\sigma^{2}$, as well as other sources of heterogeneity in firm and agent characteristics. The parameter $\beta$ represents the marginal reduction in productivity from a competitor's sabotage activities. Effort is unobservable by the principal, but all other parameters are common knowledge. Denote a linear sharing rule between the principal and the agents, which aligns the interests of the agents and principal, $S=\eta+s Q$. The agent receives a pay package of $w_{1}$ if he/ she wins promotion, otherwise the agent receives a pay package of $w_{2}$ if he/she loses the competition and stays on the current position or is forced to leave the firm and search for another position. The agent cares about his/ her total pay less the costs involved, and has exponential utility with constant absolute risk aversion $\gamma$. The agent $j$ then maximizes

$$
\max _{\mu, \theta}\left\{w_{1} p\left(\mu_{j,} \theta_{j} ; \mu_{k}, \theta_{k}\right)+w_{2}\left[1-p\left(\mu_{j}, \theta_{j} ; \mu_{k}, \theta_{k}\right)\right]-c_{j}\left(\mu_{j,} \theta_{j}\right)+S_{j}\left(\mu_{j}, \theta_{j} ; \mu_{k}, \theta_{k}\right)-\frac{\gamma}{2} s^{2} \sigma^{2}\right\}
$$

The promotion probability $p$ depends not only on an agent's own productivity, but also on that of its rival and it indirectly depends on the two agents' sabotage activities. This is formally stated as

$$
\begin{aligned}
p\left(\mu_{j}, \theta_{j} ; \mu_{k}, \theta_{k}\right) & =\operatorname{prob}\left(q_{j}>q_{k}\right) \\
& =\operatorname{prob}\left[\left(\alpha \mu_{j}-\beta \theta_{k}\right)-\left(\alpha \mu_{k}-\beta \theta_{k}\right)>\varepsilon_{k}-\varepsilon_{j}\right] \\
& =G
\end{aligned}
$$

where $\mathrm{G}$ is the distribution function of the random variable $\varepsilon_{k}-\varepsilon_{j}$, the random shocks on firm production and the agents' idiosyncratic production.

Solving the first order condition, we obtain the levels of productive effort and sabotage of agent $j$ given $w_{1}, w_{2}$, and $s$ :

$$
\begin{aligned}
& \mu_{j}=\frac{\alpha}{2 A}\left[\left(w_{1}-w_{2}\right) g(.)+s\right] \\
& \theta_{k}=\frac{\beta}{2 B}\left[\left(w_{1}-w_{2}\right) g(.)-s\right]
\end{aligned}
$$


Because the two agents are symmetric, the level of productive effort and sabotage chosen by agent $k$ are determined in the same way. We can clearly see that both effort and sabotage increase as the pay gap gets larger. Moreover, the alignment of an agent's interests with that of the principal, $s$, helps to constrain the two agents' sabotage behavior. Hence, a better way to induce effort and lower the level of sabotage is to maintain a relatively low pay gap $\left(w_{1}-w_{2}\right)$ and a better alignment of manager and shareholder interests through equity-based manager compensation.

The competitive firm must maximize the two agents' expected rents subject to a zeroprofit constraint by choosing $w_{1}, w_{2}, s$. Solving the first order condition, we get the following equilibrium pay gap $\Delta=w_{1}-w_{2}$ and the sharing rule $s$ :

$$
\begin{aligned}
& \Delta=\frac{1}{g(.)} \frac{\left(\frac{\alpha^{2}}{A}-\frac{\beta^{2}}{B}\right)}{\left(\frac{\alpha^{2}}{A}+\frac{\beta^{2}}{B}\right)}(1-s) \\
& s=\frac{1}{2 \gamma \sigma^{2}+\frac{\alpha^{2}}{A}+\frac{\beta^{2}}{B}}\left[\left(\frac{\alpha^{2}}{A}+\frac{\beta^{2}}{B}\right)-\left(\frac{\alpha^{2}}{A}-\frac{\beta^{2}}{B}\right) \Delta g(.)\right]
\end{aligned}
$$

Substituting (5a) and (5b) back into (1), we obtain the relationship between firm output $Q$ and the pay gap level $\Delta$

$$
Q=\left(\frac{\alpha^{2}}{A}-\frac{\beta^{2}}{B}\right) g(.) \Delta+\left(\frac{\alpha^{2}}{A}-\frac{\beta^{2}}{B}\right) s
$$

Several implications emerge by examining equation (6). The pay gap is determined by the tradeoff between the marginal benefit of improving manager incentives and thereby reducing moral hazard $\left(\alpha^{2} / A\right)$ and the marginal cost of encouraging strong rival competition, which induces potential sabotage behavior $\left(\beta^{2} / B\right)$. Notice that marginal benefits and marginal costs are highly related to the firm's environment that influences managers' marginal productivity of effort $\alpha$, the costs of undertaking sabotage $B$, and the damage brought about by agents' sabotage $\beta$. Moreover, when managerial interests are better align with those of principals through other governance arrangements, the moral hazard problem is less severe, and the benefit of the pay gap 
is lower. Hence, the optimal pay gap decreases with the quality of the firm's corporate governance and the managers' equity delta. Thus, the optimal pay gap is highly firm specific. Given this analysis, we form the following hypotheses:

1. $\partial \Delta / \partial \alpha>0$. Pay gap increases in a manager's marginal productivity of effort. Hence, pay gap should be larger in large and more complex firms, because a manager's marginal productivity of effort is high in such firms (i.e. Rosen (1982), Gabaix and Landier (2008)).

2. $\partial \Delta / \partial \beta<0$. Pay gap decreases in the damage associated with agent sabotage. Hence, given that Siegel and Hambrick (2005) find that team production is more important in high-tech firms, we expect pay gap to be lower in technology-intensive firms.

3. $\partial \Delta / \partial s<0$. Pay gap should be lower when managers have better incentives due to their equity holdings and other firm governance mechanisms that align their interests with those of the principals.

4. $\partial \Delta / \partial \sigma=\frac{\partial \Delta}{\partial g} \frac{\partial g}{\partial \sigma}>0$. Pay gap increases in the variance of the random production shock, which is our measure of firm risk.

The relationship between pay gap and firm output is also largely conditional on firm characteristics as indicated by equation (8). The coefficient of pay gap is increasing in the marginal benefit of improving manager incentives and reducing moral hazard $\left(\alpha^{2} / A\right)$ and the marginal cost of encouraging greater manager competition, which can lead to agent sabotage $\left(\beta^{2} / B\right)$. In light of the model predictions, we form the following testable hypotheses with regard to the relationship between pay gap and firm value:

5. $\partial Q / \partial \Delta \partial \alpha>0$ The effect of pay gap on firm value increases in marginal productivity of manager effort. Hence, we expect a greater effect of pay gap on firm value in large and complex firms.

6. $\partial Q / \partial \Delta \partial \beta<0$ The effect of pay gap on firm value decreases in the expected damage associated with agent sabotage. Therefore, we expect the effect of pay gap on firm value to fall with the level of R\&D intensity, which requires greater agent cooperation. 
7. $\partial Q / \partial \Delta \partial \sigma<0$ The effect of pay gap on firm value also falls with rising firm risk.

\section{Data and Sample Description}

\subsection{Data source}

We obtain top executive officer names and compensation data from Compustat's Execucomp. Since FAS123R substantially changed the reporting rule on equity based compensation starting in year $2006,{ }^{7}$ our sample ends in 2005 to allow equity-based compensation to be estimated on a consistent basis. Identification of the CEO is primarily based on the Chief Executive Officer code (CEOANN=CEO). The sample only includes firms with a clearly identified CEO and at least three non-CEO senior executives reported in Execucomp. Firm accounting information and stock return information are taken from Compustat and CRSP respectively. Boards of directors and other corporate governance characteristics are obtained from RiskMetrics. Because RiskMetrics begins reporting board of director information in year 1996, our sample begins in that year. Thus, our major tests are based on the 10-year sample period from 1996 to 2005.

\subsection{Variable definition}

The pay gap is measured as the difference in total compensation between the CEO and median total compensation of the other top executives who are reported in the proxy statements. We then scale the difference by taking the natural logarithm. Following Kale et al (2009), for cases where a CEO's total compensation is less than the median non-CEO executive's total compensation, which results in a negative pay gap, we monotonically transform all observations by adding a constant equal to the absolute value of the minimum gap to each observation. The pay gap measure is based on the total compensation of each of these top executives, including salary, bonus, other annual pay, the market value of restricted stock granted that year, the BlackScholes value of stock options granted that year, long-term incentive payouts, and all other compensation elements (as reported in Execucomp item TDC1). The sample mean and median

\footnotetext{
${ }^{7}$ Specifically, the FASB began requiring that the public entities report the cost of all employee stock options and other equity based compensation based on their current fair value.
} 
of pay gap is $\$ 3,023,210$ and $\$ 1,380,640$, respectively, and we observe a large cross-sectional variation. The bottom quartile of pay gap is $\$ 542,424$ and the top quartile is $\$ 3,427,720$. Meanwhile, there is a significant upward trend over time as shown in Figure 1. The median pay gap is $\$ 935,530$ in 1996 and it increases to $\$ 1,948,430$. We also use several alternative pay gap measures, including the CPS (CEO pay slice) studied by Bebchuk et al 2011, the coefficient of variation of the total compensation for the top executives and the Gini coefficient of total compensation among the top executives. We find a similar upward trend over our sample period when we use these alternative measures ${ }^{8}$. These alternative pay gap measures have a significant positive correlation with firm value, although they are far from perfectly correlated.

We measure firm value using Tobin's Q, approximated by book value of assets minus book value of equity plus market value of equity, all divided by book value of assets. Each firm's Tobin's Q measure is industry adjusted by subtracting the industry median Q, where the industry is defined by FF 49 industries using the Compustat Universe (excluding the firm in question). We examine both industry adjusted $\mathrm{Q}$ at year $(\mathrm{t}+1)$ (termed the one-year adjusted $\mathrm{Q}$ ) and the average industry adjusted Q over the next three years (termed the three-year adjusted Q). The median one-year adjusted Q and three-year adjusted Q are 0.128 and 0.125 , respectively.

We evaluate the overall strength of corporate governance based on five dimensions: (1) board composition and board monitoring; (2) blockholder monitoring; (3) anti-takeover provisions that measure the strength of the market for corporate control; (4) a CEO's formal positions and power inside the firm; (5) industry competition. To be specific, (1) includes board size (median=9), percentage of independent directors (median=0.66), percentage of busy independent directors, measured by directors who serve on more than three boards (mean=0.1, median=0). For (2), we use an indicator for when an independent blockholder is represented on the board (frequency $=0.10$ ). ${ }^{9}$ For (3), we use the entrenchment index (E index) of Bebchuk, Cohen and Farrell (2009) (median=2). For (4), we use an indicator for CEO-chair duality

\footnotetext{
${ }^{8} \mathrm{CPS}$ is the ratio of CEO total compensation over the aggregate total compensation of all top 5 executives. Coefficient of variation is the standard deviation of total compensation for all top executives divided by the mean value of total compensation for all top executives. The equation to calculate Gini coefficient is: Gini $=\frac{N+1}{N-1}-\frac{2}{N(N-1) \mu}\left(\sum_{i=1}^{n} P_{i} X_{i}\right)$ where $\mathrm{P}$ is the rank of total compensation and $X$ is the amount of total compensation for person $i$.

${ }^{9}$ Following Agrawal and Nasser(2012), I define independent director blockholders (IDB) as independent directors holding more than one percent of total shareholdings or of total votes.
} 
(frequency=0.65), while for (5) industry competition is measured by a Herfindahl index for the firm's main 4 digit SIC (median=0.03). Due to the correlation among those governance mechanisms and the potential substitution (Fahlenbrach 2009) and complementarity effects (Hartzell and Starks 2003) among them, we construct a single governance index score to capture the overall strength of a firm's governance. To be specific, each of the above variables is standardized by demeaning it and scaling it to have a unit standard deviation. Variables negatively associated with governance quality, i.e. percentage of busy independent directors, the E-index, CEO-chair duality indicator and the Herfindahl index, are multiplied by -1 . The governance index score is then calculated as the linear combination of those transformed variables, where a high score indicates a firm with better overall level of governance. The mean and median values of the governance index score are 0.06 and -0.05 , respectively. Firms whose score falls below the 25 percentile level (score=-1.63) are considered to have extremely weak corporate governance (captured by a weak governance indicator, which is one for bottom quartile firms and zero otherwise). On the other hand, firms whose score is above the 75 percentile level (score $=1.70$ ) are considered well governed, which is represented by a strong corporate governance indicator.

The median firm in our sample has total assets of $\$ 1157$ million dollars and operates in two business segments. Firms operating in multiple business segments and with above-median size are regarded as complex in the nature of its business and organizational structure, in contrast to small firms operating in single segment, which is similar to the definition used in Coles et al (2008). Technology-intensity is captured by a firm's investment in R\&D activities. We define firms that have $R \& D$ to total assets ratio greater than or equal to the 75 percentile level (R\&D/ total assets=0.04) to be technology-intensive. Note that the R\&D intensity of the sample firms is highly right skewed. We assess firm risk by looking at its stock return volatility, measured as the standard deviation of its 60-month stock returns over the past five years. ${ }^{10}$ The sample mean and median of stock return volatility is 0.13 and 0.11 , respectively. We measure an executive's alignment of interest with shareholders using the executive's equity delta, which is defined as the dollar change in his or her accumulated stock and option portfolios for a $1 \%$ change in stock price, following the approach of Core and Guay (2002). Haubrich (1994), Hall and Liebman

\footnotetext{
${ }^{10}$ For firms that have less than 5 years of public history, we use the monthly observations of stock prices that are available. However, we require a minimum of 12 consecutive monthly observations.
} 
(1998), and Core and Guay (1999) argue that a wealth-constrained and risk-averse manager can obtain powerful incentives from a large dollar equity portfolio. Our sample of CEOs has an median equity delta of $\$ 256,199$, while the median non-CEO executive's equity delta is substantially lower with a median of $\$ 25,233$. We report the sample statistics in Table 1 and all continuous variables are winsorized at 1 and 99 percentile levels.

\subsection{Negative pay gap}

Sometimes, the CEO is paid less than the median level of the non-CEO top executives and this difference leads to a negative pay gap. About $5.34 \%$ of our firm-year observations (892 out of 16699) have a negative pay gap. Some firms only have negative pay gap occasionally, while some firms persistently have CEO paid less than other top executives, i.e. Franklin Resources, Southwest Airlines, Safeguard Scientifics, Biomet, and etc. Table 3 compares negative-pay-gap firms with positive-pay-gap firms. Firms having negative pay gaps are smaller, invest significantly more in $R \& D$ expenses, and have more volatile stock returns. Their overall corporate governance mechanisms are also much stronger. A higher portion of such firms have CEOs who are founders or founding family members. In terms of industry representation, about half of the firms with negative pay gaps are in business services (FF industry 34), chips and electronic equipment (FF industry 36), Retail (FF industry 42), and Transportation (FF industry 40). The descriptive statistics is largely consistent with our predictions (1)-(3). ${ }^{11}$

\section{Empirical Results}

\subsection{The level of pay gap and firm characteristics}

We first examine the relationship of pay gap and firm characteristics. We find that pay gap is highly firm-specific and it is significantly correlated with factors reflecting the marginal benefit of managerial effort and the marginal costs of rival manager sabotage. The results in column one of Table 4 shows that firm size has a significant positive correlation with pay gap,

\footnotetext{
${ }^{11}$ Prior studies generally do not treat firms with negative compensation gaps separately. The descriptive statistics in this section shows .that firms with negative pay gaps could have different characteristics from those with positive pay gaps, Therefore we exclude them from our sample in robustness tests to make sure our main results are not purely driven by this subgroup of firms, though negative gaps are always possible under some bonus schemes.
} 
consistent with the prediction that pay gap should increase with a manager's marginal productivity of effort. The pay gap is negatively correlated with other top executives' median equity delta and the coefficient is statistically significant at 1 percent level, suggesting that when non-CEO top executive incentives are better aligned with shareholder interests, a lower pay gap is optimal. Similarly, we find pay gap decreases with the firm's corporate governance score, suggesting that when the overall corporate governance is strong enough to substantially lower manager-shareholder agency problems, the benefit of having large pay gaps is also reduced. This result is also in line with argument in Acharya, Myers and Rajan (2010) that internal incentives can substitute for other corporate governance mechanisms. Consistent with our prediction (4), we find that pay gap increases with firm risk. Surprisingly, we find no evidence that pay gap is related to firm R\&D level in any significant way, which stands in contrast with the prediction that high technology-intensive firms that bear large costs of productivity-reducing competing manager sabotage should have low pay gaps. One possible reason is that although high-tech firms generally suffer greatly from uncooperative rival competition, they are also generally hard to monitor due to their high technology-intensity, which requires larger pay gap to control for a potential manager moral hazard problem. Therefore, we further examine whether high-tech firms significantly reduce pay gap when the overall corporate governance mechanisms are strong enough to control managerial moral hazard. As predicted, this is indeed what we find: pay gap is negatively related to $\mathrm{R} \& \mathrm{D}$ intensity when moral hazard is kept low by strong corporate governance, thus causing managerial collaboration to be a priority for these firms.

Our results from using indicator variables in place of continuous variables are similar to the regression results in column one. We find that large and complex firms have larger pay gaps than small and single segment firms. High risk firms also have significantly larger pay gaps than low risk firms. Firms with above-median equity deltas for non-CEO executives have an average 6 percent lower pay gap than firms with non-CEO executive equity deltas below the sample median. Firms with strong corporate governance have an average pay gap that is 12 percent lowers than firms with weak governance.

\subsection{Pay gap level and firm value}

We next test the effect of pay gaps on firm value measured by one-year and three-year industry-adjusted Tobin's Qs. Table 5 reports the regression results of one-year and three-year 
industry-adjusted Q on pay gap, controlling for other factors that earlier studies document to affect firm performance. Although we find pay gap is negatively correlated with firm performance, it is statistically insignificant once we include firm fixed effects. This result is in line with equation (8) in our model: the effect of pay gap on firm value is conditional on firm specific parameters, and both the sign and magnitude of the coefficient are determined by the marginal benefit of reducing managerial moral hazard and the marginal costs of non-CEO manager sabotage. We also include a quadratic term on pay gap to test if there is an invert-U relationship. We find that neither pay gap, nor its squared value, are significantly related to firm performance (measured by short term or long term performance), contradicting the findings reported by Aggarwal et al (2011).

Since firms could have large pay gaps either because CEO pay is very high or non-CEO manager pay is relatively low, we test if the pay gap-firm performance relationship depends on the source of the large pay gap. We first estimate the abnormal CEO pay using the residual from regressing total CEO compensation on firm size, market to book ratio, year and industry fixed effects. The abnormal compensation for median non-CEOs is calculated in the same way. We observe that $42.35 \%$ of firm-year observations have positive abnormal CEO compensation, while $59.22 \%$ of firm-year observations have negative abnormal median non-CEO compensation. We then interact the pay gap with an indicator for positive CEO abnormal pay and an indicator for negative non-CEO abnormal pay in model 4 and model 8 of Table 5. Once again, we find statistically insignificant relationship between pay gap and firm performance. Furthermore, the relationship is not related to whether CEO pay is too high or non-CEO pay is too low.

Our hypotheses in section 2 suggest that the relationship between pay gap and firm value relies on the marginal benefit of reducing managerial moral hazard, which is closely related to manager marginal productivity. Following this logic, we test the effect of pay gap on firm performance conditional on firm complexity. As modeled in Rosen (1982) and Gabaix and Landier (2008), marginal productivity of manager effort increases with firm size and complexity. We test prediction (5) by interacting pay gap with a complex-firm indicator, with the results reported in Table 6. Consistent with our hypothesis, we find a significant positive coefficient on the interaction term in both the one-year and three-year industry-adjusted Q regressions, suggesting that complex firms reap greater benefits from having larger pay gaps. The effect of 
pay gap on firm performance also depends on the severity of a firm's moral hazard problem. In firms where strong corporate governance tightly limits the moral hazard problem, the marginal benefit of reducing CEO moral hazard is lower and so is the benefit of raising pay gap on firm value. Consistent with this prediction, we find that the marginal effect of pay gap on firm value significantly falls with the overall strength of a firm's corporate governance. The magnitude is economically large: the marginal effect of pay gap on one-year industry adjusted Q falls by $70 \%$ if the firm's corporate governance moves from the bottom quartile to the top quartile, while the marginal effect of pay gap on three-year industry adjusted Q becomes negative when a firm's corporate governance index is in the top quartile. Similarly, we find that the marginal benefit of having a large pay gap to improve managerial incentives and hence raise firm value is greatly reduced when non-CEO executives have high equity deltas. The marginal effect of pay gap on three-year industry adjusted $Q$ falls from a significantly positive to a significantly negative coefficient, if non-CEO executive equity deltas move from the bottom quartile to the top quartile for our sample.

We test hypothesis 6 by interacting pay gap with R\&D intensity. Consistent with the hypothesis that the effect of pay gap on firm value decreases with the potential cost of competing manager rivalry, we find that the coefficient on the interaction of pay gap and R\&D intensity is negative and significant. The marginal effect of pay gap on one-year adjusted $\mathrm{Q}$ is 84 percent lower for high R\&D-intensity firms than for firms without significant $R \& D$ expenditures. The coefficient of pay gap in the firm value regressions also depends on firm riskiness. Specifically, the estimates in the last two columns of Table 6 indicate that the marginal effect of pay gap on firm value significantly falls as firm risk increases. The coefficient of pay gap is 0.038 for firms in the bottom quartile of stock return volatility, compared to -0.014 for firms in the top quartile. This is strongly consistent with prediction (7) that riskier firms suffer more from large pay gaps. Our result complements the findings in Bloom and Michel (2002), which documents that large pay gaps are associated with higher manager turnover and shorter manager tenure, and this impact can be intensified under more volatile operating conditions.

\subsection{Predicted pay gap and firm value}

We test the relation between pay gap and firm value in Table 7 using the fitted value for pay gap. The reason for using predicted pay gap instead of the actual level is that the actual pay 
gap can be affected by random shocks from time to time and hence, the relationship we document in Table 6 could be spuriously driven by those random shocks. Using fitted values helps to control for the effects from these random shocks.

Our results remain the same under this specification. Predicted pay gap significantly reduces firm value in small and single segment firms, while it significantly increases firm value in large, multi-segment firms (conglomerates). The positive effect of predicted pay gap on firm value significantly falls if overall corporate governance is strong or if non-CEO top executives have high equity deltas. The effect of predicted pay gap on firm value even becomes negative if the firm has a corporate governance score above 0.5 or the median non-CEO top executive has an equity delta that is high enough (above the 95 percentile of the sample). The effect of predicted pay gap on industry-adjusted Q also falls with R\&D intensity, and its effect is reduced by almost $70 \%$ if a firm with no material R\&D expenditures begins to invest heavily in R\&D and moves its R\&D intensity level to the top quartile of the sample (R\&D/total assets= 0.04). Similarly, the positive effect of predicted pay gap on firm value also falls significantly as a firm's risk level rises.

\section{2003 Tax Reform as a Quasi-Natural Experiment}

\subsection{The impact of dividend tax cut}

The Jobs and Growth Tax Relief Reconciliation Act of 2003 drastically cut the dividend tax to a flat rate of 5 or 15 percent $^{12}$ from the previous progressive tax schedule with a top rate of 35 percent. The agency model of dividend tax in Chetty and Saez (2010) shows that a dividend cut leads to lower agency problems, because it increases manager after-tax wealth obtained from their equity holdings and thus, results in a better alignment of interest between managers and shareholders. We term this as an increase in effective ownership, because its effect is equivalent to an increase in manager share ownership. Empirical evidence has shown that corporate behavior changes around the 2003 dividend tax cut. For instance, Chetty and Saez (2005) find that regular dividends rose sharply right after the 2003 tax cut. Cheng, Hong and Shue (2012)

\footnotetext{
${ }^{12}$ More precisely, taxpayers in the bottom two income tax brackets face a new dividend tax rate of 5 percent, while taxpayers in the top four brackets face a new dividend tax rate of 15 percent.
} 
find that after this dividend cut, managers are less likely to push pet projects such as "corporate goodness".

In addition to dividend tax cut, the Jobs and Growth Tax Relief Reconciliation of 2003 also cuts the capital gains tax significantly. The capital gains tax decreased from rates of $8 \%$, $10 \%$, and $20 \%$ to $5 \%$ and $15 \%$. The drop in capital gains tax shifts executive preferences towards more stock based compensation, which can also result in increased managerial ownership. We use the 2003 tax reform as a largely exogenous event, which increases managers' alignment of interest with shareholders and hence, reduces managerial moral hazard incentives. We then study the corresponding changes in pay gaps and the effect of pay gaps on firm performance.

The intuition behind the Chetty and Saez (2005) model is straightforward. The manager can do three things with a firm's cash $X$ : pay out dividends $D$, invest $I$ in a productive project that generates net profits $f(I)$ for shareholders, or invest $\mathbf{J}$ in a pet project that gives the manager private benefits of $\mathrm{g}(\mathrm{J})$. Assuming the manager holds $\alpha$ percent of the firm's total shares outstanding, the manger's pay has the following structure:

$$
V=\alpha\left(1-t_{d}\right)\left[D+\frac{f(I)+X-D}{1+\gamma}\right]+\frac{g(J)}{1+\gamma}
$$

The manager's effective ownership stake $\alpha\left(1-t_{d}\right)$ increases with a drop in the dividend tax rate, $t_{d}$. Meanwhile, the marginal cost of pet projects $\partial g / \partial I=\alpha\left(1-t_{d}\right) \partial f / \partial I$ increases as the dividend tax rate $t_{d}$ is lowered. Hence, after the tax reform, we expect a decrease in manager's investment in pet projects, and an increase in real investment $I$ or dividend payment $D$, depending on whether the initial investment $\mathrm{I}$ is at the first-best level. Moreover, large shareholders also effectively have larger shareholdings after the dividend tax cut that encourage them to monitor managers more closely, which reduces the agency problems further.

\subsection{The change of the pay gap level}

We expect a decrease in pay gap following the 2003 tax cut, because the marginal benefit of having a large pay gap is reduced due to the increase in effective managerial ownership. Figure 2 (a) shows the change in the pay gap around 2003, after taking out the time trend. 
Consistent with our expectation, there is a clear drop in the de-trended pay gap in year 2003, and the drop is across the whole distribution of individual firm pay gaps. The drop is most pronounced for firms whose pay gaps are in the top quartile. Figure 2 (b) further shows that both CEO total compensation and median non-CEOs' total compensation drops following the 2003 dividend tax cut, and the CEO total compensation falls significantly more than non-CEO managers' total compensation. We then investigate whether different firms respond to this tax cut differently. Figure 2 plots the changes in the de-trended pay gap over time, conditional separately for firms with different characteristics. Simple firms (i.e. small and single segment firms) cut their pay gaps more aggressively than complex (large and conglomerate) firms. High R\&D firms also reduce their pay gaps more dramatically than firms with little investment in R\&D. In addition, high risk firms cut their pay gaps more aggressively than low risk firms. We then examine the changes in pay gaps based on a firms' dividend payout status. We investigate firms that do not pay a dividend over the whole sample period, firms that pay out dividends over the entire sample period, and firms that start to pay dividends after 2003 . We find that firms that initiated dividend payouts after 2003 cut their pay gaps most significantly, suggesting that these firms' behavior was affected most by the tax cut.

We next formally test whether the average change in pay gaps occurs after the 2003 dividend tax cut using the following specification:

$$
\log \left(\text { pay }_{-} \text {gap }\right)_{i t}=\alpha+\beta_{1} \text { post }_{i t}+\beta_{2}(t-2003)_{i t}+\beta_{3} \text { post }_{i t} \times(t-2003)_{i t}+X_{i t} \gamma+\mu_{i t}
$$

where post is defined as an indicator variable for the post-tax-cut 2003-2005 period, $t$-2003 captures the time-series trend, and $X_{i t}$ is a vector of firm level controls. We also include firm fixed effects to control for unobservable time-invariant firm level factors. Table 8 column 1 displays the result of this regression. Although the pay gap has an overall upward trend $\left(\beta_{2}>0\right)$, it decreases significantly after the 2003 dividend tax cut, controlling for the time series trend. The coefficient $\beta_{1}$ is significantly negative at the one percent level. In terms of economic magnitude, the pay gap declines by 10 percent for the average firm $(\$ 302,321$ dollars) in the post-tax-cut period (2003-2005, relative to the pre-tax-cut period (1996-2002). Column 2 and column 3 of Table 8 show that both the level of CEO compensation and median non-CEO executive compensation decline after 2003 tax cut, but the level of CEO compensation appears to 
decline more than the level of median non-CEO compensation. The model of Chetty and Saez (2005) in equation (9) further suggests that firms most affected by the tax reform are those having higher managerial stock ownership $(\alpha)$ and paying out dividends $(D>0)$. Hence, we test whether these firms tend to cut their pay gaps more than other firms. The three-way interaction term of the post-tax reform indicator, CEO's aggregate shareholding as a percentage of total shares outstanding (CEO ownership) and a firm's dividend payout status prior to the tax reform in column 4 of Table 8 is negative and significant at the one percent level. This is consistent with the prediction that firms that pay out dividend and have CEOs with large ownership positions respond to the tax reform more strongly than other firms and cut their pay gap more aggressively. In unreported regressions, we find that such firms reduce their pay gaps by cutting CEO compensation more aggressively than cutting median non-CEO compensation, relative to the remaining firms. In column 5, we replace CEO ownership with median non-CEO executive ownership, and the three-way interaction term is also negative, suggesting that when non-CEO top executives have larger ownership positions in dividend-paying firms, these firms also cut their pay gaps more aggressively, but the effect is not statistically significant. Finally, we look at the ownership difference between the CEO and median non-CEO top executive and interact it with an indicator for a firm's dividend payout status in column 6. We find that firms having a large ownership differences between the CEO and other top executives and regularly paying cash dividends prior to the tax reform reduce their pay gap significantly more than other firms.

We next examine whether the magnitude of the pay gap reduction is conditional on firm characteristics by estimating the following regression model:

$$
\begin{aligned}
\log \left(\text { pay_gap }_{i t}=\right. & \alpha+\beta_{1} \text { post }_{i t}+\beta_{2} \text { post }_{i t} \times \text { firm_type }_{i t}+\beta_{4} \text { firm_type }_{i t} \\
& +\beta_{5}(t-2003)_{i t}+\beta_{6} \text { post }_{i t} \times(t-2003)_{i t}+X_{i t} \gamma+\mu_{i t}
\end{aligned}
$$

Consistent with the diagram in figure 2 (b), we find a smaller decrease in the pay gaps of complex firms compared with simple firms, after controlling for a time trend and other firm characteristics, and the difference in pay gap reductions is statistically significant at 5 percent level. High R\&D firms and high risk firms reduce their pay gaps more than other firms, although the difference is not statistically significant. Similarly, the difference in pay gap reductions by firms with good and bad corporate governance is not statistically significant. We also look at the 
average change of the pay gap based on firm dividend payout status. Without taking into account the level of managerial ownership, we find no significant difference in the pay gap changes of dividend and non-dividend paying firms. When we use the predicted probability of paying a cash dividend, instead of the firm's actual dividend payout status, ${ }^{13}$ we find no evidence suggesting that changes of pay gaps around the 2003 tax reform is related to the dividend payout propensity.

\subsection{The relation between pay gap and firm value before and after tax cut}

In this section, we examine whether the effect of pay gaps on firm performance changes after an exogenous rise in effective managerial ownership caused by the 2003 dividend tax cut. Managers have greater incentives to put in more effort after the dividend tax reform act because their wealth is more closely tied to firm value after the exogenous increase in their share ownership. Meanwhile, for the same reason, managers are less willing to sabotage their colleagues, everything else being equal. Thus, we expect firm value to increase after the tax cut. Moreover, the marginal effect of the pay gap on motivating executives to put in more effort and thereby reducing moral hazard declines, because the marginal productivity of effort falls with the level of effort, but the marginal cost of effort increases with the level of effort. Therefore, we expect the marginal effect of pay gap on firm value to decline after the 2003 tax reform act, relative to the pre-tax-cut period. We formally test this prediction by estimating the following regression:

$$
\begin{aligned}
{\text { industry_adjusted_Q } Q_{i t}} & \alpha_{0}+\alpha_{1} \log (\text { pay_gap })_{i t}+\alpha_{2} \text { post }+\alpha_{3}(t-2003)_{i t} \\
& +\left[\beta_{1} \log (\text { pay_gap })_{i t}+\beta_{2}(t-2003)_{i t}\right] \times \text { post }_{i t} \\
& +X_{i t} \gamma+\mu_{i t}
\end{aligned}
$$

The results are reported in Table 9. We find that $\alpha_{1}$ is positive and statistically insignificant, consistent with our findings in Table 5 that on average pay gap does not have a significant impact on firm value. $\beta_{1}$ is negative and statistically significant and $\alpha_{1}+\beta_{1}<0$, suggesting that a larger pay gap reduces firm value after the 2003 tax reform, and the impact is statistically significant. This is consistent with our prediction that the marginal effect of pay gap

\footnotetext{
${ }^{13}$ The probability of paying out dividends is estimated using a logistic model following Denis and Osobov (2008). Specifically, the independent variables are firm size measured by logarithm of total assets, market to book ratio, percentage change of total assets, retained earnings/book value of equity and EBIT/total assets. The independent variables are measured at one year before the dividends are paid out.
} 
declines after an exogenous increase in managerial ownership. $\alpha_{2}$ is significantly positively, consistent with our prediction that firm value on average increases after the dividend tax cut.

We next use a difference-in-difference approach and compare the changes in pay gap coefficients across firms with different characteristics. Specifically, we compare complex versus simple firms, high versus low R\&D intensity firms, high versus low risk firms, and good versus bad governance firms. Formally, the regression specification is as follows:

$$
\text { industry adjusted } \begin{aligned}
Q_{i t} & =\alpha_{0}+\alpha_{1} \log (\text { pay_gap })_{i t}+\alpha_{2} \log (\text { pay_gap })_{i t} \times \text { firm_type }_{i t}+\alpha_{3} \text { post }+\alpha_{4}(t-2003)_{i t} \\
& +\left[\beta_{1} \log (\text { pay_gap })_{i t}+\beta_{2} \log (\text { pay_gap })_{i t} \times \text { firm_type }_{i t}+\beta_{3}(t-2003)_{i t}\right] \times \text { post }_{i t} \\
& +X_{i t} \gamma+\mu_{i t}
\end{aligned}
$$

The coefficient $\beta_{2}$ shows us the average change in the pay gap effects for high minus low-type firms. The results are reported in the Table 9. While the effect of pay gap on firm value generally falls after the tax reform $\left(\beta_{1}<0\right)$, there is significant cross-group heterogeneity. Complex firms experience a much smaller decline in the marginal effect of pay gap relative to simple firms $\left(\beta_{2}>0\right)$. On the other hand, high-risk firms and high-tech firms have a much larger decline in the pay gap effect on firm value, compared to low-risk firms and low R\&D intensity firms respectively $\left(\beta_{2}<0\right)$. Similarly, the decline in the marginal effect of the pay gap after the tax reform is also larger for well-governed firms compared to weakly-governed firms $\left(\beta_{2}<0\right)$. These cross-group comparisons are all statistically significant.

The unexpected dividend tax cut provides us with a quasi-natural experiment which gives us new insights into how firms adjust senior manager financial incentives in the face of an exogenous change in the contracting environment. We find that firms appear to respond to such changes by adjusting their executive compensation arrangements to take into account the changing incentives due to taxes. Moreover, the effect of one incentive mechanism on improving firm value becomes weaker if other incentive mechanisms are reinforced by changes in government regulatory or tax policies.

\section{Robustness}




\subsection{Instrumental variable regressions using GMM}

Our quasi-natural experiment presented in section 5 is one approach to controlling for endogeneity in our results. We next use a conventional approach for taking endogeneity into account, namely using instrumental variable regressions. To implement this approach, we use annual industry median pay gap level and industry number of internal CEO successions to instrument for a firm's pay gap level. The interactions of pay gap with indicators for various classes of firms are instrumented by interactions of the two exogenous instruments with these firm class indicators. For instance, the interaction of pay gap with the complex firm indicator is instrumented by two exogenous instruments: the interactions of industry median pay gap and the industry number of internal CEO successions with the complex firm indicator.

The instrumental variable regression model is estimated with GMM. The IV-GMM estimator is more efficient than the 2SLS estimator when the number of exogenous instrumental variables is more than the number of endogenous variables and thus, the model is overidentified. Table 11 reports the main results of estimating this model. The findings are qualitatively the same as those found in Tables 5. The Hansen's J statistics for testing the overidentifying restriction has insignificant $\mathrm{P}$-value, indicating that the null hypothesis that the exogenous variables are appropriately independent of the error process cannot be rejected, which is to say the exclusion requirement is met. Both the F-statistics and the Cragg-Donald Wald test used to detect a weak instruments problem indicate that the instruments are sufficiently correlated with the endogenous regressors.

\subsection{Other examinations for robustness}

Finally, alternative measures of pay gap are used to check the robustness of the main results. Three alternative measures of pay gap we explore are: 1) CPS, defined as the slice of CEO total compensation as a percentage of the aggregate total compensation of the top five executives, which is used in Bebchuk et al (2011);2) the Gini-coefficient of total compensation

among the top five executives, which is used in Kale et al (2009), Aggarwal et al (2011), and Bebchuk et al (2011); 3) the coefficient of variation of the total compensation among the top five executives. The major findings of the study continue to hold under these alternative specifications. 
As further robustness analysis, we delete financial and utility firms, due to their heavy regulatory burden and distinctly different structures of their balance sheets. We also delete firms whose CEO is also a founder, because their incentives may be very different from those of professional managers. Lastly, we exclude firms with negative pay gaps. Again, our results remain qualitatively unchanged.

\subsection{Horizontal Pay Gap}

We also look at pay gaps among non-CEO executives. The reason for this procedure is that executives are more likely to compare themselves to other executives with similar positions and status. Hence, non-CEO top executive incentives are more likely to be affected by the compensation of other non-CEO executives. Moreover, a hierarchical structure could well exist among non-CEO executives. These executives may first need to be promoted to a core-executive position, for example holding the $\mathrm{COO}$ position, before they can compete for the CEO position. We define the pay gap among non-CEO executives as the horizontal pay gap, and it is calculated as the dollar difference between the $75^{\text {th }}$ percentile and the $25^{\text {th }}$ percentile of total compensation of all non-CEO executives. The distribution of the horizontal pay gaps is reported in the summary statistics of Table 10. The horizontal pay gap is significantly lower than the pay gap between the $\mathrm{CEO}$ and the median non-CEO executive.

Our results using the horizontal pay gap are largely similar to our earlier results using our primary pay gap measure. On average, large horizontal pay gaps significantly increase firm value based on an analysis of the full sample. This effect is significantly reduced as firm R\&D intensity and stock return volatility rise, which is largely consistent with our prior findings. The effect of the horizontal pay gap on firm value is greater for large and complex firms, relative to small and single segment firms, but the difference is not statistically significant. The effect of the horizontal pay gap on firm value also falls with the quality of the firm's corporate governance and the median non-CEO executive's equity delta, but again the difference is not statistically significant. This result also holds even if we include the pay gap between the CEO and the median non-CEO executive as an additional control variable. ${ }^{14}$

\footnotetext{
${ }^{14}$ The results are available upon request.
} 


\section{Conclusion}

We use the often-neglected importance of team production in our empirical study to shed new light on the relationship between pay gap and firm performance. Given that large pay gaps can unintentionally invite value-reducing office politics and non-cooperative behavior by competing managers, we posit a simple principal-agent model that predicts that the pay gap level is determined by the tradeoff between reducing CEO shirking and consumption of private benefits of control and improving team production incentives. Moreover, the relationship between pay gap and firm value also largely depends on a firm's marginal benefit of reducing managerial moral hazard incentives and the marginal cost of inducing non-cooperative manager behavior.

In particular, our analysis highlights that the pay gap decision should be highly firm specific. It is more beneficial in larger, more complex firms and conglomerates, where the marginal productivity of manager effort is higher and hence, a board's main goal is to find ways to induce more managerial effort. The pay gap is lower, when other firm governance mechanisms in place are strong enough to ensure that managerial efforts are close to the firstbest level and consequently making a large pay gap unnecessary. The pay gap level is also related to the likelihood of competing manager sabotage of each other and the potential loss of firm value from sabotage. We find pay gaps to be lower when increasing team production and eliminating non-cooperative managerial behavior is a firm's major concern, such as for high R\&D intensity firms with strong corporate governance.

We then test the relationship between firm value and pay gap. This relationship is clearly conditional on firm specific characteristics. We find that the effect of pay gap on improving firm performance is significantly positive when a firm has potentially more manager-shareholder agency problems and the moral hazard problem associated with shirking or excessive perquisite consumption is large. On the other hand, the effect of pay gap on firm performance is largely reduced and can even become negative, when managerial shirking is not a major concern, while improved team collaboration and productivity is a first order of magnitude issue. To be specific, large pay gaps significantly increases firm value in complex firms. Its effect significantly falls and can even become negative when a firm has large R\&D investment, or when a firm has high 
risk, or when senior manager incentives are better aligned with shareholders through either large equity deltas for senior managers or well-constructed corporate governance systems.

Our primary finding is further reinforced by using the 2003 tax reform as a quasi-natural experiment, an event which increases manager after-tax wealth obtained from their equity holdings and lowers the managerial moral hazard problem. We find firms on average reduce their pay gap following this exogenous tax code change. Moreover, the size of the pay gap reduction is heterogeneous across different classes of firms. Also, the marginal effect of pay gap on firm value significantly falls after the tax reform act, suggesting that managerial compensation arrangements that improve firm value are weakened when existing financial incentive mechanisms are reinforced by exogenous external shocks.

Our empirical results help explain the apparently contradictory findings in the existing research that report significant positive and negative relationships between pay gap and firm value. We find that there is no simple relationship between pay gap and firm value across the full sample of publicly listed firms. Instead, we find that the level of pay gap and its effect on firm value depend on firm characteristics and these effects can change over time with major changes in a firm's contracting environment. Thus, no simple rule of thumb exists to determine whether a large or small pay gap is value enhancing for all firms. It follows that pushing pay gap in one direction is likely to benefit some firms, while at the same time harming others. 


\section{Reference}

Acharya, Viral V., Stewart C. Myers, and Raghuram G. Rajan, 2011, The internal governance of firms, Journal of Finance 66, 689-720.

Aggarwal, Rajesh K., Yihui Pan, and Huijing Fu, 2012, An empirical investigation of internal governance, SSRN eLibrary.

Aggarwal, Rajesh K., and Andrew A. Samwick, 2003, Performance incentives within firms: The effect of managerial responsibility, Journal of Finance 58, 1613-1650.

Agrawal, Anup, and Tareque Nasser, 2012, Blockholders on boards and CEO compensation, turnover and firm value, working paper

Armstrong, Chris, Alan Jagolinzer and David Larcker, 2009, Chief executive officer equity incentives and accounting irregularities, Working paper.

Bebchuck, Cremers and Peyers, Forthcoming, The CEO pay slice, Journal of Financial Economics.

Bloom, Matt, 1999, The performance effects of pay dispersion on individuals and organizations, The Academy of Management Journal 42, 25-40.

Bloom, Matt, and John G. Michel, 2002, The relationships among organizational context, pay dispersion, and managerial turnover, Academy of Management Journal 45, 33-42.

Bognanno, Michael L., 2001, Corporate tournaments, Journal of Labor Economics 19, 290-315.

Cheng, Ing-Haw, Harrison G. Hong, and Kelly Shue, 2012, Do managers do good with other peoples' money?, SSRN eLibrary.

Chetty, Raj, and Emmanuel Saez, 2005, Dividend taxes and corporate behavior: Evidence from the 2003 dividend tax cut, Quarterly Journal of Economics 120, 791-833.

Chetty, Raj, and Emmanuel Saez, 2010, Dividend and corporate taxation in an agency model of the firm, American Economic Journal: Economic Policy 2, 1-31.

Conyon, Martin J., I. Peck Simon, and Graham V. Sadler, 2001, Corporate tournaments and executive compensation: Evidence from the U.K, Strategic Management Journal 22, 805-815.

Denis, David J., and Igor Osobov, 2008, Why do firms pay dividends? International evidence on the determinants of dividend policy, Journal of Financial Economics 89, 62-82.

Eriksson, Tor, 1999, Executive compensation and tournament theory: Empirical tests on danish data, Journal of Labor Economics 17, 262-280. 
Fahlenbrach, Rüdiger, 2009, Shareholder rights, boards, and CEO compensation, Review of Finance 13, 81-113.

Gabaix, Xavier, and Augustin Landier, 2008, Why has CEO pay increased so much?, Quarterly Journal of Economics 123, 49-100.

Hambrick, Donald C., and Richard A. D'Aveni, 1992, Top team deterioration as part of the downward spiral of large corporate bankruptcies, Management Science 38, 1445-1466.

Hartzell, Jay C., and Laura T. Starks, 2003, Institutional investors and executive compensation, Journal of Finance 58, 2351-2374.

Hayward, Mathew L. A., and Donald C. Hambrick, 1997, Explaining the premiums paid for large acquisitions: Evidence of CEO hubris, Administrative Science Quarterly 42, 103127.

Henderson, Andrew D., and James W. Fredrickson, 2001, Top management team coordination needs and the ceo pay gap: A competitive test of economic and behavioral views, Academy of Management Journal 44, 96-117.

Jason, D. Shaw, Nina Gupta, and John E. Delery, 2002, Pay dispersion and workforce performance: Moderating effects of incentives and interdependence, Strategic Management Journal 23, 491-512.

Kale, Jayant R., Ebru Reis, and Anand Venkateswaran, 2009, Rank-order tournaments and incentive alignment: The effect on firm performance, Journal of Finance 64, 1479-1512.

King, Gary, Richard Nielsen, Carter Coberley and James Pope, 2011, Comparative effectiveness of matching methods for causal inference, Working paper.

Lazear, Edward P., 1989, Pay equality and industrial politics, Journal of Political Economy 97, 561-580.

Lazear, Edward P., and Sherwin Rosen, 1981, Rank-order tournaments as optimum labor contracts, Journal of Political Economy 89, 841-864.

Lee, Kin Wai, Baruch Lev, and Gillian Hian Heng Yeo, 2008, Executive pay dispersion, corporate governance, and firm performance, Review of Quantitative Finance and Accounting 30, 315-338.

Main, Brian G. M., Charles A. O'Reilly, III, and James Wade, 1993, Top executive pay: Tournament or teamwork?, Journal of Labor Economics 11, 606-628.

Masulis, Ronald W. and Mobbs, H. Shawn, 2011, Are all insider directors the same? Evidence 
from the external directorship market, Journal of Finance 66, 823-872

Masulis, Ronald W. and Shage Zhage, 2011, Compensation gap among top executives: Evidence of tournament incentives or productivity differentials, working paper.

Parrino, Robert, 1997, CEO turnover and outside succession a cross-sectional analysis, Journal of Financial Economics 46, 165-197.

Rosen, Sherwin, 1981, The economics of superstars, The American Economic Review 71, 845858

Rosen, Sherwin, 1982, Authority, control, and the distribution of earnings, Bell Journal of Economics 13, 311-323.

Siegel, Phyllis A., and Donald C. Hambrick, 2005, Pay disparities within top management groups: Evidence of harmful effects on performance of high-technology firms, Organization Science 16, 259-274. 


\section{Appendix 1}

\begin{tabular}{|c|c|}
\hline Variable Name & Definition \\
\hline \multicolumn{2}{|l|}{ Compensation Variables } \\
\hline Pay Gap & $\begin{array}{l}\text { CEO total compensation (TDC1) -median total } \\
\text { compensation of non-CEO executives }\end{array}$ \\
\hline Equity Delta & $\begin{array}{l}\text { Dollar change in executive's stock and option portfolios } \\
\text { for a } 1 \% \text { change in stock price. Calculated follow Core and } \\
\text { Guay (2002) }\end{array}$ \\
\hline Positive CEO Abnormal Pay Indicator & $\begin{array}{l}\text { CEO Abnormal Pay is the residual from regressing total } \\
\text { CEO compensation on firm size, market to book, year and } \\
\text { industry fixed effects. Positive CEO abnormal Pay } \\
\text { indicator equals one if CEO abnormal pay is greater than } \\
\text { zero. }\end{array}$ \\
\hline Negative non-CEO Abnormal Pay Indicator & $\begin{array}{l}\text { Non-CEO Abnormal Pay is the residual from regressing } \\
\text { total compensation of median non-CEO on firm size, } \\
\text { market to book, year and industry fixed effects. Negative } \\
\text { non-CEO abnormal Pay indicator equals one if CEO } \\
\text { abnormal pay is less than zero. }\end{array}$ \\
\hline Horizontal Pay Gap & $\begin{array}{l}\text { 75th percentile of total compensation for all non-CEO } \\
\text { executives }-25 \text { th percentile of total compensation for all } \\
\text { non-CEO executives }\end{array}$ \\
\hline CEO Ownership & $\begin{array}{l}\text { The aggregate shared held by CEO over the total shares } \\
\text { outstanding }\end{array}$ \\
\hline Non-CEO Ownership & $\begin{array}{l}\text { The median number of shares held by all non-CEO } \\
\text { executives over the total shares outstanding }\end{array}$ \\
\hline \multicolumn{2}{|l|}{ Firm Characteristic Variables } \\
\hline One-year Adjusted Q & $\begin{array}{l}\text { Industry adjusted Tobin's Q measured at the end of year } \\
t+1\end{array}$ \\
\hline Three-year Adjusted Q & Industry adjusted Tobin's $Q$ averaged over year $t+1$ to $t+3$ \\
\hline Firm risk & $\begin{array}{l}\text { The standard deviation of monthly stock return over the } \\
\text { prior five years }\end{array}$ \\
\hline Governance index score & $\begin{array}{l}\text { A linear combination of a set of transformed variables that } \\
\text { capture the corporate governance mechanisms }\end{array}$ \\
\hline Diversified & $\begin{array}{l}\text { A indicator variable which equals one if the firm has more } \\
\text { than on business segments }\end{array}$ \\
\hline Leverage & $\begin{array}{l}\text { Market Leverage }=(\text { debt in current liability }+ \text { long term } \\
\text { debt }) /(\text { debt in current liability }+ \text { long term debt }+ \text { market } \\
\text { value of equity })\end{array}$ \\
\hline Complex Firm Dummy & $\begin{array}{l}\text { Equals one if the firm's total assets are above sample } \\
\text { median and has more than one business segments }\end{array}$ \\
\hline High-Tech Firm Dummy & $\begin{array}{l}\text { Equals one if the firm's R\&D/ total assets ratio is above } \\
0.04 \text {, and zero otherwise }\end{array}$ \\
\hline High Risk Firm Dummy & $\begin{array}{l}\text { Equals one if the firm's stock return volatility over the } \\
\text { prior five years is above the sample median }\end{array}$ \\
\hline Strong governance dummy & $\begin{array}{l}\text { Equals one if the firm's governance index score is above } \\
1.71\end{array}$ \\
\hline Dividend Payer Indicator & $\begin{array}{l}\text { Equals one if the firm pays out dividend prior to the tax } \\
\text { reform in } 2003\end{array}$ \\
\hline
\end{tabular}


Figure 1 Time Series Trend of Pay gap

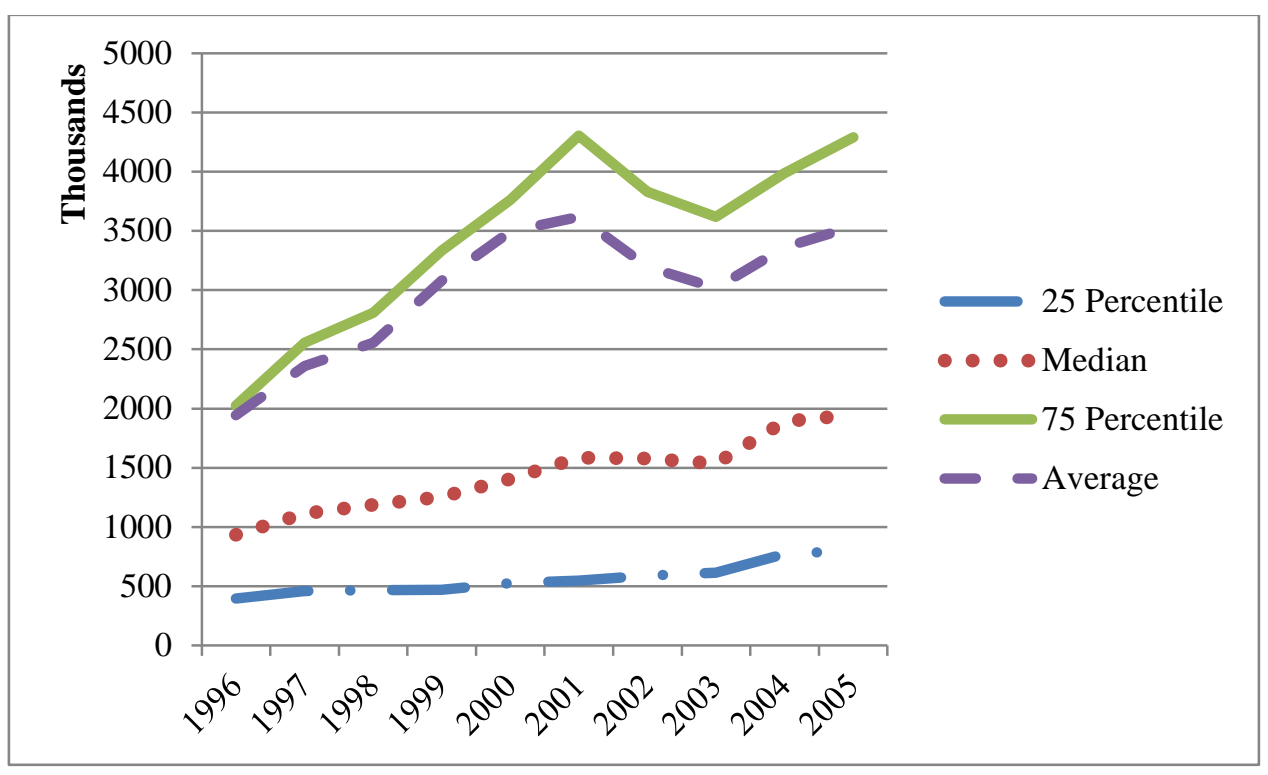


Figure 2 De-trended Pay Gap (\$ Thousands) Before and After 2003

\section{a. Pay Gap Quartiles}

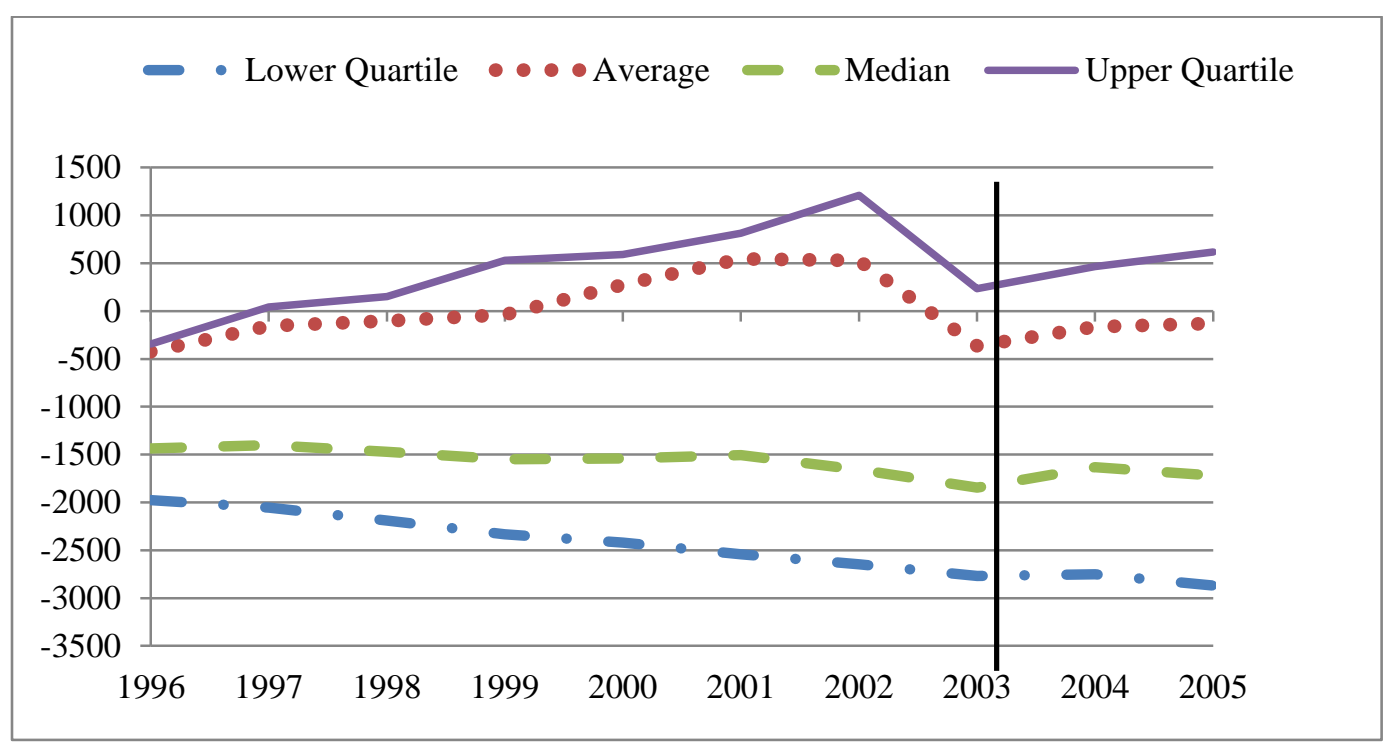

b. CEO total compensation (de-trended) vs. total compensation (de-trended) for median non-CEO executive

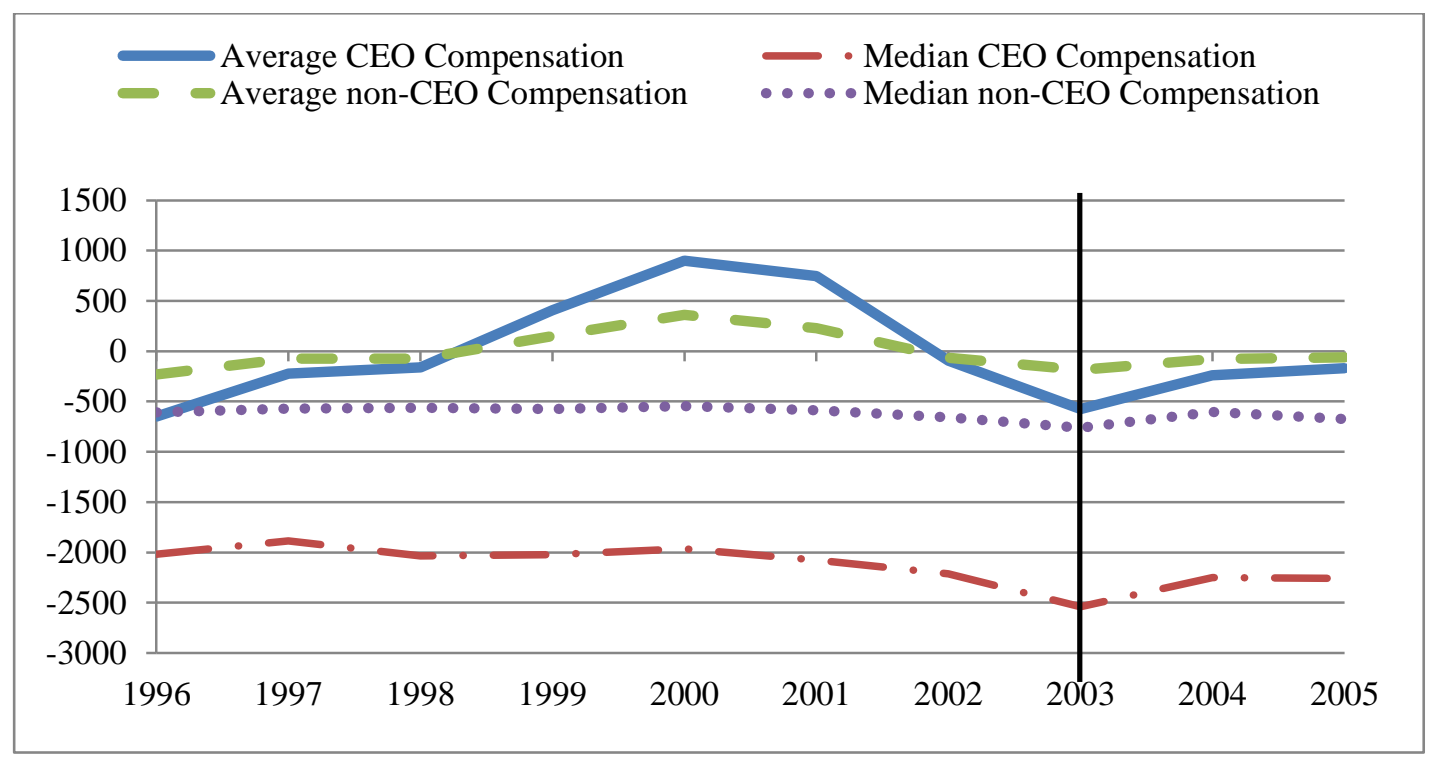


Figure 3 De-trended Pay Gap (\$ Thousands) Before and After 2003 Conditional on Firm Types

a. Low R\&D vs. High R\&D Firms

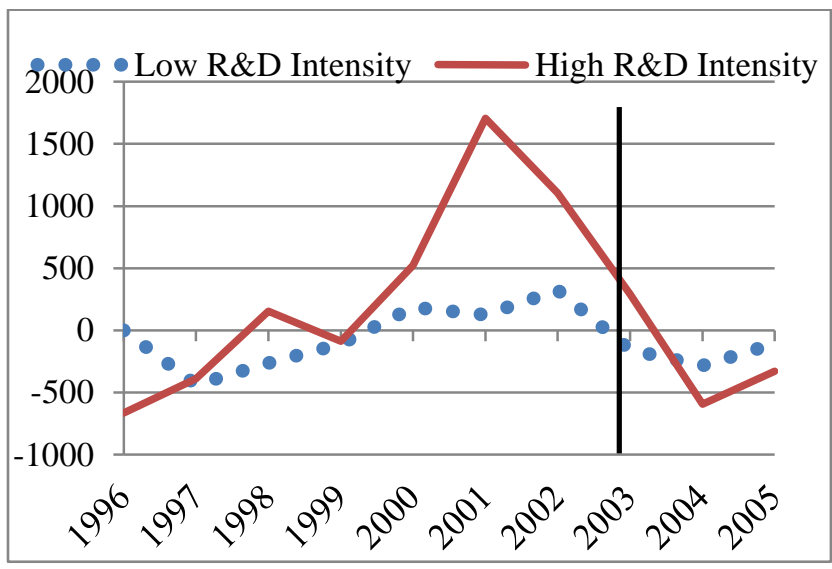

c. Dividend Paying Status

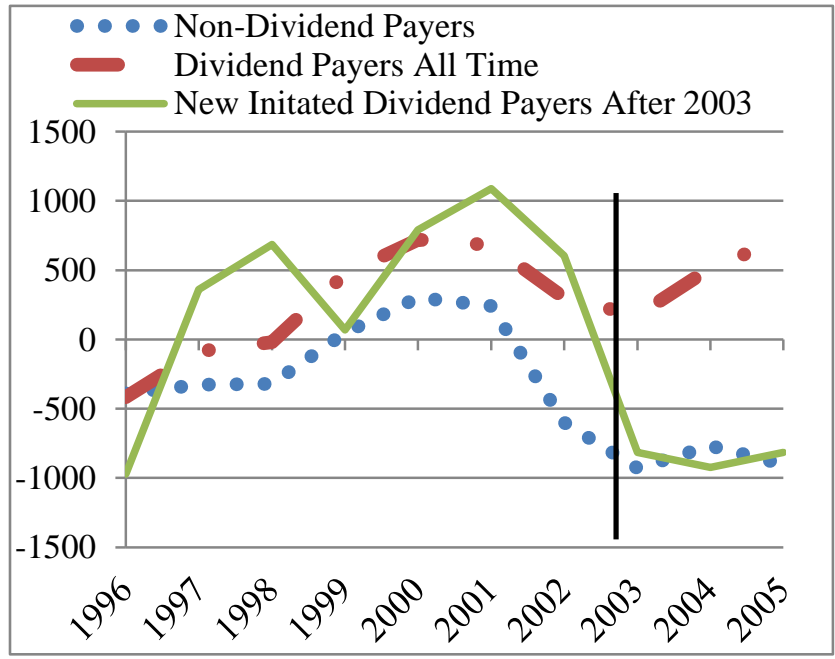

e. Simple vs. Complex Firms

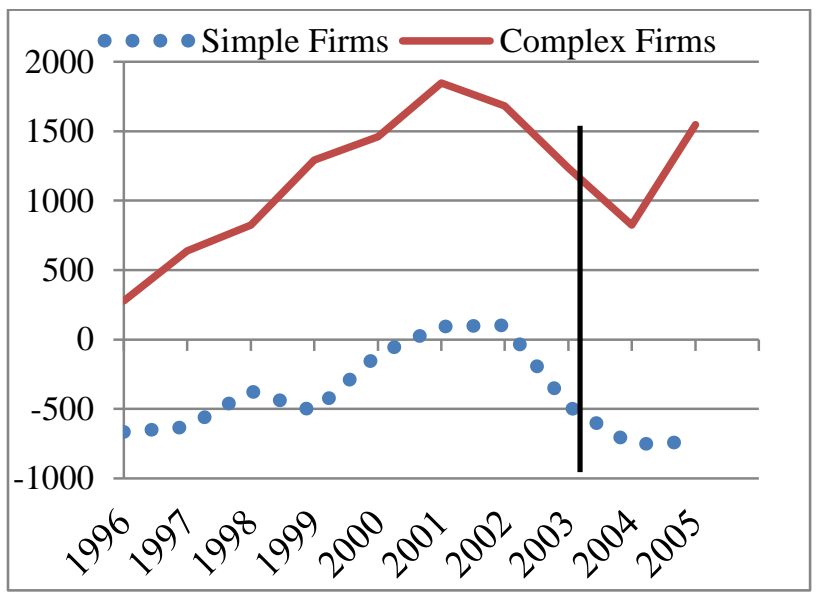

b. Low Risk vs. High Risk Firms

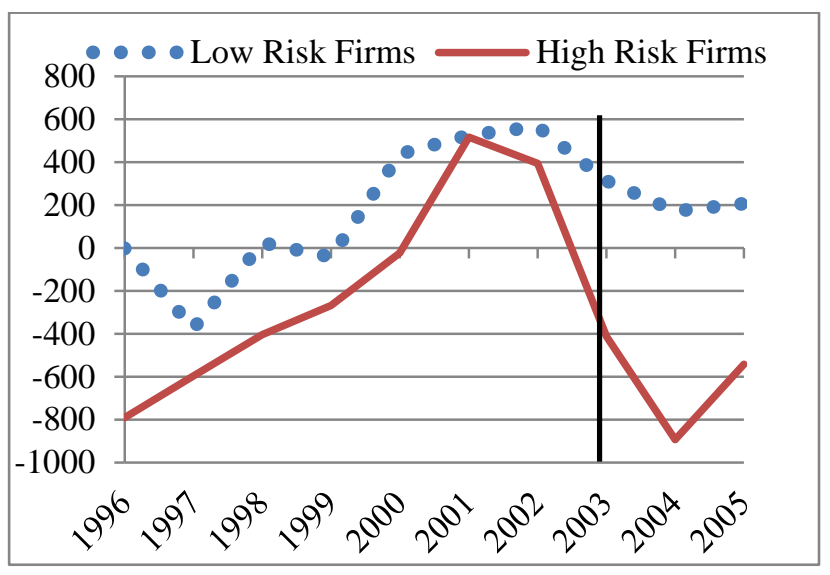

\section{d. Bad vs. Good Governance Firms}

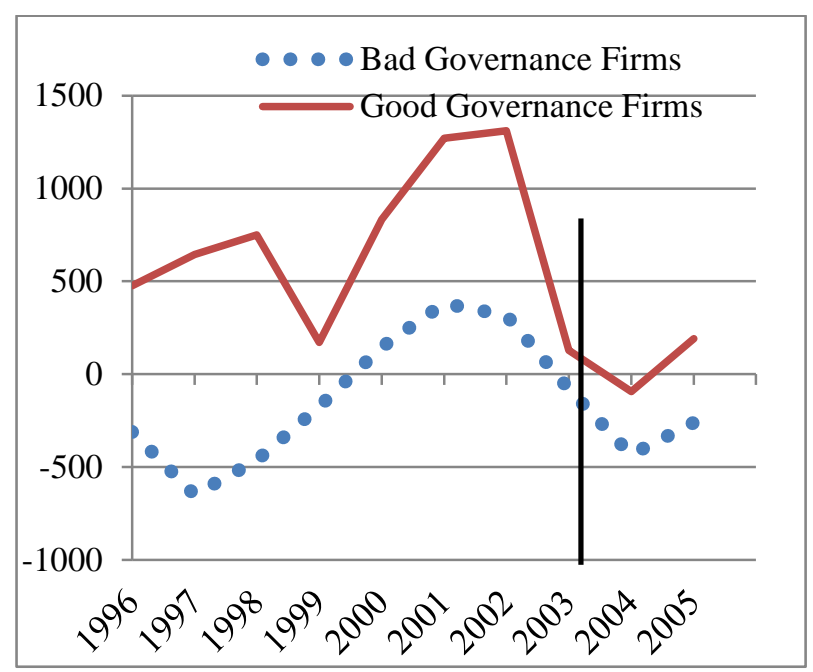




\section{Table 1 Descriptive Statistics}

This table reports the summary statistics of key variables of sample firms in the period of 1996-2005. All variables are winsorized at one and 99 percent levels. Detailed variable definitions can be found in Appendix 1.

\begin{tabular}{|c|c|c|c|c|}
\hline $\begin{array}{l}\text { Variable Name } \\
\text { Key Variables }\end{array}$ & Mean & $\begin{array}{l}\text { Lower } \\
\text { Quartile }\end{array}$ & Median & $\begin{array}{l}\text { Upper } \\
\text { Quartile }\end{array}$ \\
\hline Adjusted Q & 0.59 & -0.14 & 0.15 & 0.79 \\
\hline Pay Gap (\$thousands) & 3023.21 & 542.42 & 1380.64 & 3427.72 \\
\hline Log (Pay Gap) & 7.82 & 7.31 & 7.76 & 8.38 \\
\hline Total Assets (\$millions) & 5427.17 & 434.40 & 1157.72 & 3633.65 \\
\hline Number of Business Segments & 2.22 & 1 & 2 & 3 \\
\hline Governance Index Score & 0.10 & -1.63 & -0.07 & 1.70 \\
\hline RD/Total Assets & 0.03 & 0 & 0 & 0.04 \\
\hline Firm Risk & 0.13 & 0.08 & 0.11 & 0.16 \\
\hline Log (CEO Equity Delta) & 12.64 & 11.60 & 12.45 & 13.45 \\
\hline Log (Median Non-CEO Equity Delta) & 10.20 & 9.11 & 10.21 & 11.25 \\
\hline \multicolumn{5}{|l|}{ Firm Characteristics } \\
\hline CEO Tenure & 6.31 & 2 & 4 & 9 \\
\hline CEO Chairman Dummy & 0.63 & N/A & N/A & N/A \\
\hline Board Size & 9 & 7 & 9 & 11 \\
\hline Board Independence & 0.65 & 0.55 & 0.66 & 0.79 \\
\hline Percentage of Busy Independent Director & 0.1 & 0 & 0 & 0.20 \\
\hline Presence of IDB & 0.10 & N/A & N/A & N/A \\
\hline Entrenchment Index & 1.75 & 1 & 3 & 4 \\
\hline Market Leverage & 0.22 & 0.04 & 0.17 & 0.35 \\
\hline Capx/Total Assets & 0.04 & 0.02 & 0.03 & 0.05 \\
\hline
\end{tabular}

\begin{tabular}{lllll} 
Alternative Measures of Pay Gap & & & \\
\hline CPS & 0.37 & 0.29 & 0.37 & 0.44 \\
Coefficient of Variation & 0.65 & 0.45 & 0.61 & 0.79 \\
Gini Coefficient & 0.35 & 0.25 & 0.33 & 0.43 \\
\hline
\end{tabular}

Correlation among Alternative Pay Gap Measures

\begin{tabular}{lcccc} 
& & & Coefficient of & \\
& Pay Gap & CPS & Variation & Gini Coefficient \\
\cline { 2 - 5 } Pay Gap & 1 & $0.53^{* * *}$ & $0.48^{* * *}$ & $0.47^{* * *}$ \\
CPS & & 1 & $0.58^{* * *}$ & $0.54^{* * *}$ \\
Coefficient of Variation & & & 1 & $0.97^{* * *}$ \\
Gini Coefficient & & & 1 \\
\hline \hline
\end{tabular}




\section{Table 2 Time Series Trend of Pay Gap (\$Thousands)}

This table reports the summary statistics of pay gap between the CEO and median non-CEO executive for each sample year. Panel A reports the statistics using our primary pay gap measure, which the dollar difference between CEO total compensation and the median non-CEO executive total compensation. Panel B reports alternative measures. CPS is the CEO pay slice constructed in Bebchuk et al 2011, which is ratio of CEO total compensation over the aggregate total compensation of other top 5 executives. The other two alternative measures are the coefficient of variation of the total compensation of all top executives, and the Gini coefficient of the total compensation of all top executives.

Panel A: Pay Gap = CEO total compensation - median non-CEO executive total compensation

\begin{tabular}{ccccc} 
Year & Mean & Lower Quartile & Median & Upper Quartile \\
\hline 1996 & 1943.71 & 394.82 & 935.53 & 2026.07 \\
1997 & 2358.5 & 458.56 & 1113.94 & 2557.25 \\
1998 & 2555.9 & 468.077 & 1186.52 & 2809.53 \\
1999 & 3079.04 & 470.06 & 1253.38 & 3333.16 \\
2000 & 3493.99 & 528.07 & 1407.66 & 3761.61 \\
2001 & 3618.82 & 547.75 & 1586.83 & 4302.45 \\
2002 & 3196.96 & 590.91 & 1578.23 & 3829.78 \\
2003 & 3015.95 & 612.86 & 1536.24 & 3616.8 \\
2004 & 3359.86 & 774.19 & 1890.7 & 3988.75 \\
2005 & 3538.75 & 800.2 & 1948.43 & 4288.38 \\
\hline \hline
\end{tabular}

Panel B: Alternative Measures

\begin{tabular}{|c|c|c|c|}
\hline \multicolumn{4}{|c|}{ Sample Median Year by Year } \\
\hline Year & $\mathrm{CPS}$ & Coefficient of Variation & Gini Coefficient \\
\hline 1996 & 0.35 & 0.56 & 0.31 \\
\hline 1997 & 0.36 & 0.576 & 0.326 \\
\hline 1998 & 0.362 & 0.582 & 0.329 \\
\hline 1999 & 0.365 & 0.604 & 0.335 \\
\hline 2000 & 0.368 & 0.611 & 0.342 \\
\hline 2001 & 0.375 & 0.618 & 0.345 \\
\hline 2002 & 0.378 & 0.62 & 0.345 \\
\hline 2003 & 0.38 & 0.612 & 0.338 \\
\hline 2004 & 0.385 & 0.614 & 0.337 \\
\hline 2005 & 0.39 & 0.634 & 0.345 \\
\hline
\end{tabular}


Table 3 Negative Pay Gap Firms vs. Positive Pay Gap Firms

This table compares the summary statistics of key variables between firms with negative pay gaps and firms with positive pay gaps in the period of 1996-2005. All variables are winsorized at one and 99 percent. Detailed variable definitions can be found in Appendix 1.

Total Assets (million dollars)

Number of Business Segments

RD/Total Assets

Firm Risk

Log (CEO Equity Delta)

Log (Median Non-CEO Equity

Delta)

Governance Index Score

CEO is the Founder

CEO is Founder Family Member
Firms with Positive Pay Gap

Mean Median

5430.63

2.23

0.03

0.13

12.63

1186.29

1

0

0.11

12.45

10.21

0.08

10.21

$-0.11$

$6 \%$

$3 \%$
Firms with Negative Pay Gap

Mean Median

5367.8

2.06

758.37

0.06

1

0

0.17

0.15

12.88

12.45

10.12

10.08

0.78

$17 \%$

$4 \%$ 
Table 4 The Determinants of Pay gap

This table shows the results of fixed effects OLS regression of Log (Pay gap) on firm characteristics. The dependent variable is Log (Pay gap) at time t. Independent variables are measured at year t-1.The detailed definition of each variable is explained in Appendix 1. Standard errors are in parentheses and are computed using heteroskedasticity robust standard errors, clustered at the firm level. The symbol ${ }^{* * *},{ }^{* *}$, and ${ }^{*}$ denote statistical significance at $1 \%, 5 \%$, and $10 \%$ levels, respectively.

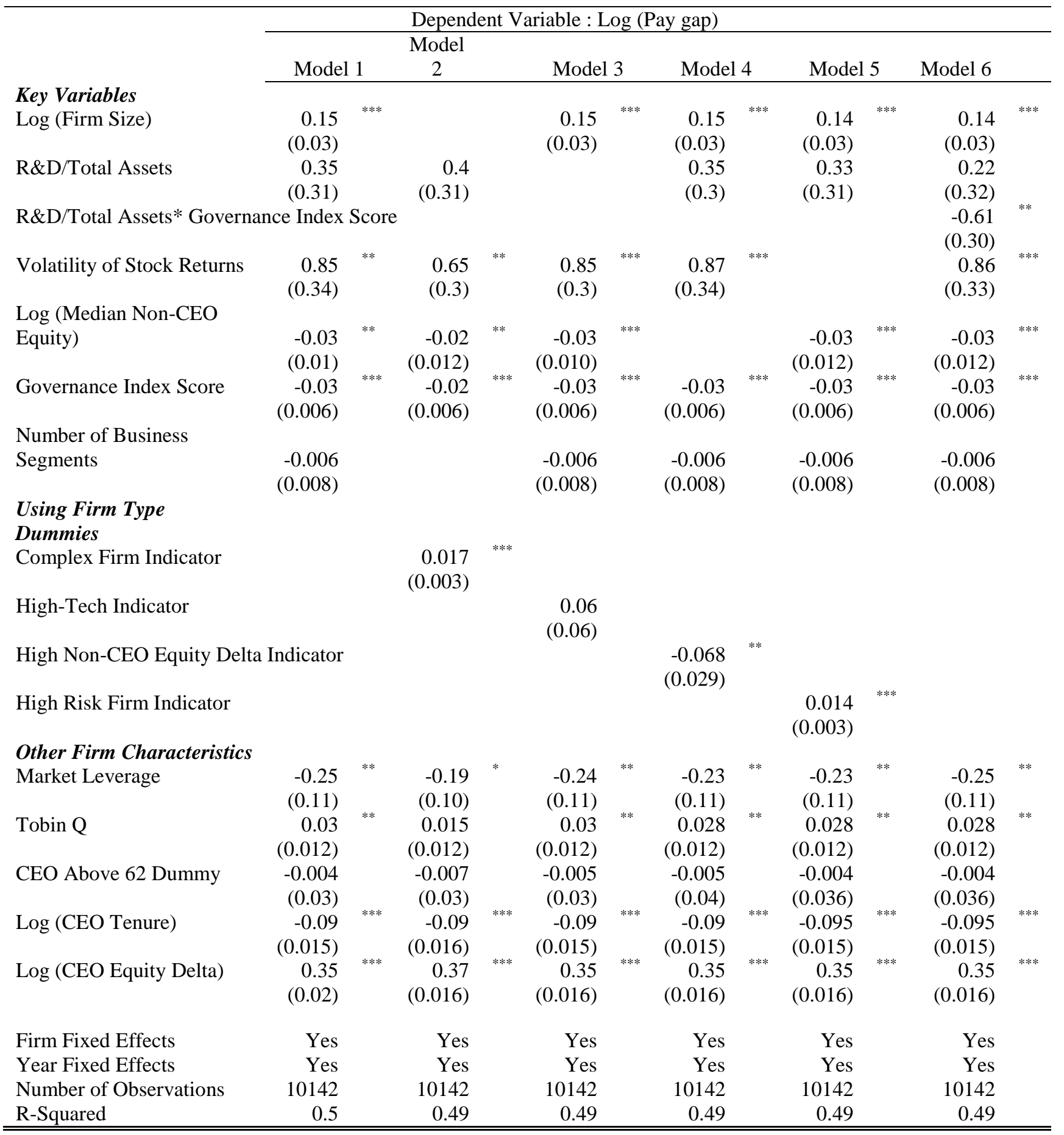


Table 5 Effect of Pay gap on Firm Value: Full Sample

This table reports the fixed effects OLS regression of firm value on Log (Pay gap) and other firm characteristics. The one-year adjusted Tobin's Q is measured at the end of year $t+1$, and the three-year adjusted Tobin's $Q$ is the average adjusted Tobin's $Q$ from time $t+1$ to $t+3$. All independent variables are measured at the end of year t. The detailed definition of each variable is explained in Appendix 1. Standard errors are in parentheses and are computed using heteroskedasticity robust standard errors, clustered at the firm level. The symbol ${ }^{* * *}, * *$, and ${ }^{*}$ denote statistical significance at $1 \%, 5 \%$, and $10 \%$ levels, respectively. 


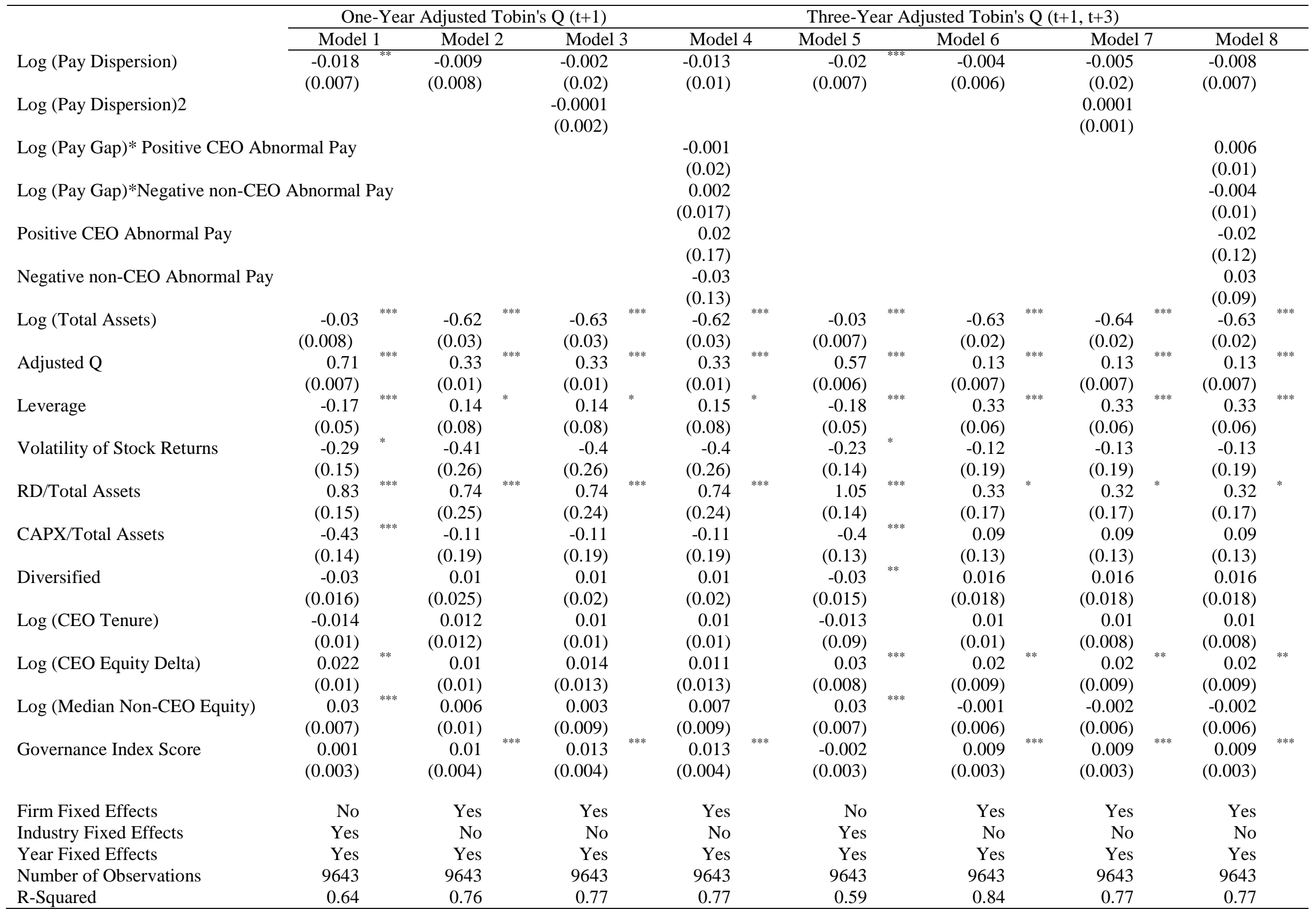


Table 6 Effect of Pay Gap on Firm Value Conditional on Firm Type

This table reports the fixed effects OLS regression of firm value on Log (Pay gap) and other firm characteristics, conditional on firm type. The one-year adjusted Tobin's Q is measured at the end of year $t+1$, and the three-year adjusted Tobin's $Q$ is the average adjusted Tobin's $Q$ from time $t+1$ to $t+3$. All independent variables are measured at the end of year t. The same set of firm level control variables as in Table 5 is included in the regressions, although they are not reported in order to save space.. Standard errors are in parentheses and are computed using heteroskedasticity robust standard errors, clustered at the firm level. The symbol ${ }^{* * *},{ }^{* *}$, and ${ }^{*}$ denote statistical significance at $1 \%, 5 \%$, and $10 \%$ levels, respectively.

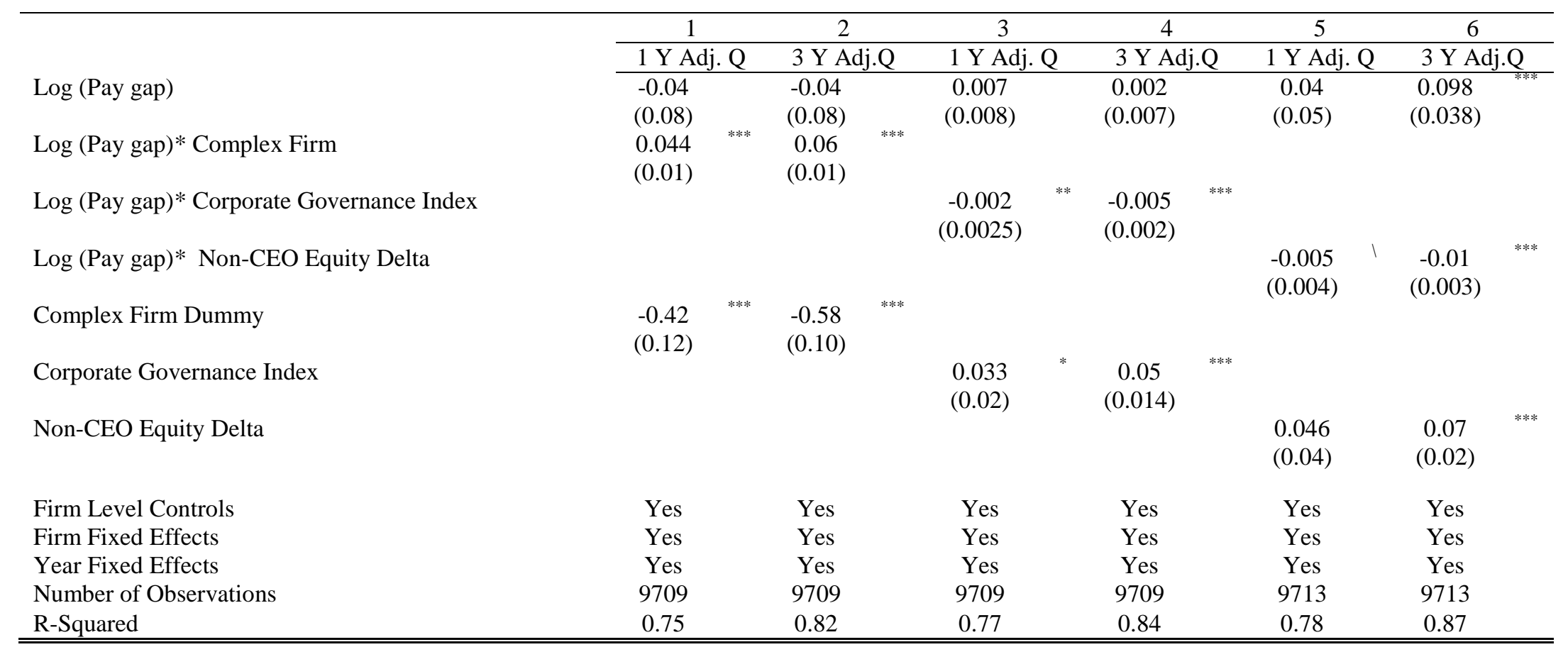




\begin{tabular}{|c|c|c|c|c|c|c|c|c|}
\hline \multirow{4}{*}{ Log (Pay gap) } & \multirow{2}{*}{\multicolumn{2}{|c|}{$\begin{array}{c} \\
1 \text { Y Adj. Q }\end{array}$}} & \multirow{2}{*}{\multicolumn{2}{|c|}{$\begin{array}{c}8 \\
3 \text { Y Adj.Q } \\
\end{array}$}} & \multirow{2}{*}{\multicolumn{2}{|c|}{$\begin{array}{c}9 \\
1 \text { Y Adj. Q }\end{array}$}} & \multirow{2}{*}{\multicolumn{2}{|c|}{$\begin{array}{c}10 \\
3 \text { Y Adj.Q }\end{array}$}} \\
\hline & & & & & & & & \\
\hline & 0.04 & $* * *$ & 0.03 & $* * *$ & 0.09 & $* * *$ & 0.07 & $* * *$ \\
\hline & $(0.01)$ & & $(0.008)$ & & $(0.019)$ & & $(0.01)$ & \\
\hline \multirow[t]{2}{*}{ Log (Pay gap)* R\&D/TA } & -0.84 & $* * *$ & -0.52 & $* * *$ & & & & \\
\hline & $(0.11)$ & & $(0.08)$ & & & & & \\
\hline \multirow[t]{2}{*}{ Log (Pay gap)* Volatility of Stock Return } & & & & & -0.65 & $* * *$ & -0.45 & $* * *$ \\
\hline & & & & & $(0.11)$ & & $(0.08)$ & \\
\hline \multicolumn{9}{|l|}{ Non-CEO Equity Delta } \\
\hline \multirow[t]{2}{*}{$\mathrm{R} \& \mathrm{D} / \mathrm{TA}$} & 0.75 & $* * *$ & 0.45 & $* * *$ & & & & \\
\hline & $(0.13)$ & & $(0.06)$ & & & & & \\
\hline Volatility of Stock Return & & & & & $\begin{array}{c}0.45 \\
(0.08)\end{array}$ & $* * *$ & $\begin{array}{c}0.33 \\
(0.06)\end{array}$ & $* * *$ \\
\hline Firm Level Controls & Yes & & Yes & & Yes & & Yes & \\
\hline Firm Fixed Effects & Yes & & Yes & & Yes & & Yes & \\
\hline Year Fixed Effects & Yes & & Yes & & Yes & & Yes & \\
\hline Number of Observations & 9713 & & 9713 & & 9700 & & 9700 & \\
\hline R-Squared & 0.77 & & 0.84 & & 0.77 & & 0.84 & \\
\hline
\end{tabular}


Table 7 Pay Gap and Firm Value: Using Predicted Pay Gap

This table reports the fixed effects OLS regression of firm value on Predicted log (pay gap) and other firm characteristics, conditional on firm type. Predicted log(pay gap) is estimated using model 1 in Table 4. The one-year adjusted Tobin's Q is measured at the end of year $t+1$, and the three-year adjusted Tobin's Q is the average adjusted Tobin's $Q$ from time $t+1$ to $t+3$. All independent variables are measured at the end of year t. The same set of firm level control variables as in Table 5 is included in the regressions, although they are not reported in order to save space. Standard errors are in parentheses and are computed using heteroskedasticity robust standard errors, clustered at the firm level. The symbol ${ }^{* * *},{ }^{* *}$, and ${ }^{*}$ denote statistical significance at $1 \%, 5 \%$, and $10 \%$ levels, respectively.

Log (Predicted Pay gap)

Log (Predicted Pay gap)* Complex Firm

Log $($ Predicted Pay gap)* Corporate Governance Index

Log (Predicted Pay gap)* Non-CEO Equity Delta

Log (Predicted Pay gap)* R\&D/TA

Log (Predicted Pay gap)* Volatility of Stock Return

Complex Firm Dummy

Corporate Governance Index

Non-CEO Equity Delta

\section{$\mathrm{R} \& \mathrm{D} / \mathrm{TA}$}

Volatility of Stock Return

Firm Level Controls

Firm Fixed Effects

Year Fixed Effects

Number of Observations

R-Squared

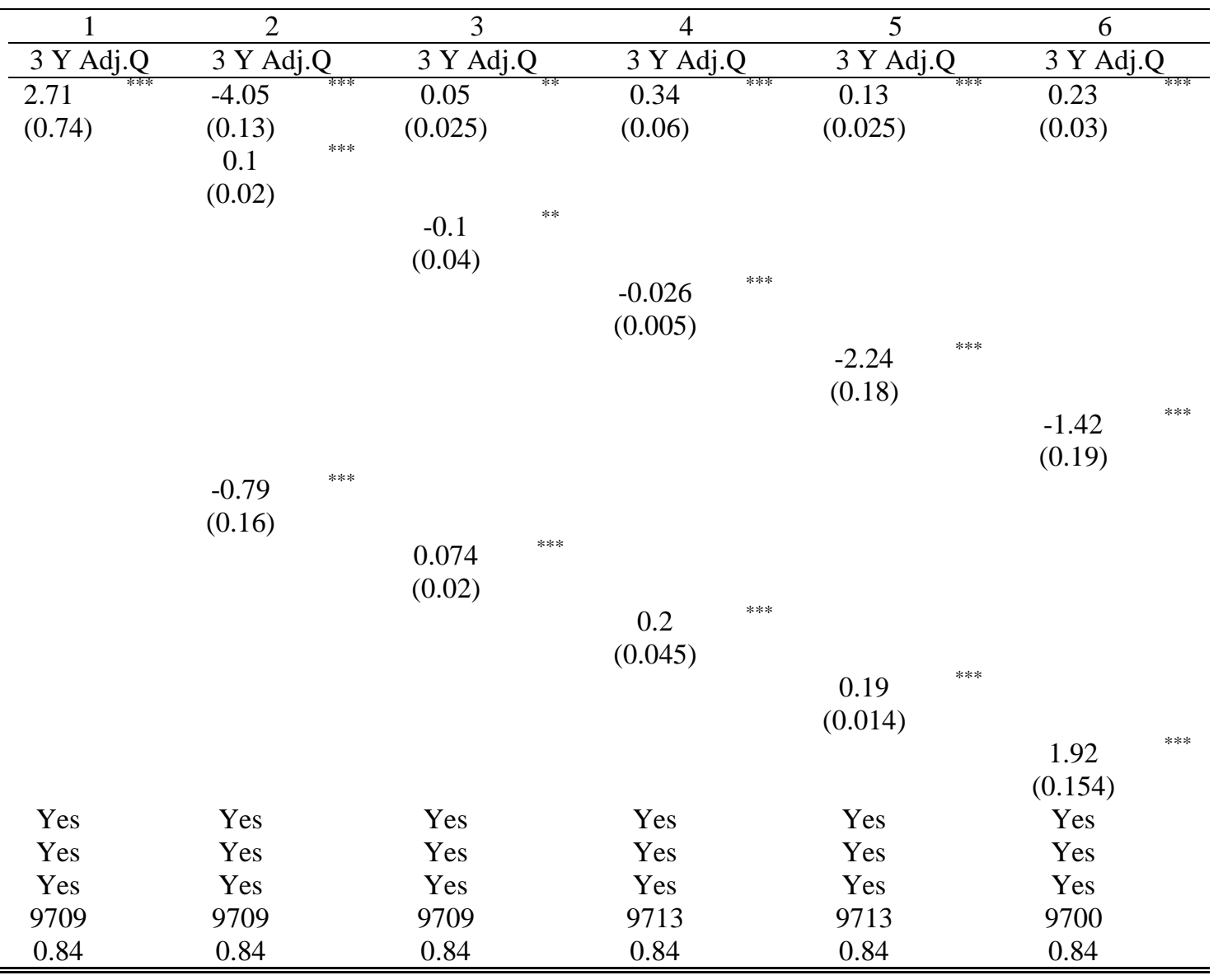


Table 8 Change of Pay Gap Before and After 2003 Tax Cut

This table shows the results of fixed effects OLS regression of Log (Pay gap) on firm characteristics, a post-tax cut indicator and a trend variable. The dependent variable in model 1, 4, 5 and 6 is $\log$ (Pay gap) at end of year t. The dependent variable in model 2 is $\log$ (CEO total compensation) at end of year t. The dependent variable in model 3 is $\log$ (median non-CEO total compensation) at end of year $t$. The same set of firm level control variables as in Table 4 is included in the regressions, and they are measured at year $\mathrm{t}-1$. Those variables are not reported to save space. Standard errors are in parentheses and are computed using heteroskedasticity robust standard errors, clustered at the firm level. The symbol ${ }^{* * *}, * *$, and ${ }^{*}$ denote statistical significance at $1 \%, 5 \%$, and $10 \%$ levels, respectively. 


\begin{tabular}{|c|c|c|c|c|c|c|c|c|c|c|c|c|}
\hline \multirow[b]{2}{*}{$\begin{array}{l}\text { Key Variables } \\
\text { Post Indicator }\end{array}$} & \multicolumn{2}{|c|}{$\begin{array}{c}\text { Model } 1 \\
\text { Y= Log (Pay } \\
\text { Gap) }\end{array}$} & \multicolumn{2}{|c|}{$\begin{array}{c}\text { Model } 2 \\
\mathrm{Y}=\log (\mathrm{CEO} \\
\text { Pay })\end{array}$} & \multicolumn{2}{|c|}{$\begin{array}{c}\text { Model } 3 \\
\mathrm{Y}=\log (\text { Median non- } \\
\text { CEO Pay) }\end{array}$} & \multicolumn{2}{|c|}{$\begin{array}{c}\text { Model } 4 \\
\mathrm{Y}=\log (\text { Pay } \\
\text { Gap) }\end{array}$} & \multicolumn{2}{|c|}{$\begin{array}{c}\text { Model } 5 \\
\mathrm{Y}=\text { Log }(\text { Pay } \\
\text { Gap) }\end{array}$} & \multicolumn{2}{|c|}{$\begin{array}{c}\text { Model } 6 \\
\mathrm{Y}=\log (\text { Pay } \\
\text { Gap) }\end{array}$} \\
\hline & $\begin{array}{r}-0.1 \\
(0.036)\end{array}$ & *** & $\begin{array}{r}-0.13 \\
(0.028)\end{array}$ & $* * *$ & $\begin{array}{r}-0.12 \\
(0.019)\end{array}$ & $* * *$ & $\begin{array}{r}-0.14 \\
(0.037)\end{array}$ & $* * *$ & $\begin{array}{r}-0.11 \\
(0.037)\end{array}$ & $* * *$ & $\begin{array}{r}-0.14 \\
(0.04)\end{array}$ & $* * *$ \\
\hline $\begin{array}{l}\text { Post * CEO Ownership* Dividend Payer } \\
\text { Indicator }\end{array}$ & & & & & & & $\begin{array}{r}-0.024 \\
(0.008)\end{array}$ & $* * *$ & & & & \\
\hline $\begin{array}{l}\text { Post * Median Non-CEO Ownership* Di } \\
\text { Indicator }\end{array}$ & lend Payer & & & & & & & & $\begin{array}{l}0.005 \\
(0.12)\end{array}$ & & & \\
\hline $\begin{array}{l}\text { Post* Ownership Difference* Dividend P } \\
\text { Indicator }\end{array}$ & & & & & & & & & & & $\begin{array}{r}-0.023 \\
(0.008)\end{array}$ & *** \\
\hline $\begin{array}{l}\text { Other Interaction Terms } \\
\text { Post* CEO ownership }\end{array}$ & & & & & & & $\begin{array}{r}0.015 \\
(0.005)\end{array}$ & $* * *$ & & & & \\
\hline $\begin{array}{l}\text { CEO Ownership* Dividend Payer } \\
\text { Indicator }\end{array}$ & & & & & & & $\begin{array}{r}0.028 \\
(0.008)\end{array}$ & $* * *$ & & & & \\
\hline Post* Median Non-CEO ownership & & & & & & & & & $\begin{array}{r}-0.089 \\
(0.08)\end{array}$ & & & \\
\hline $\begin{array}{l}\text { Median Non-CEO Ownership* Dividend } \\
\text { Indicator }\end{array}$ & lyer & & & & & & & & $\begin{array}{r}-0.03 \\
(0.07)\end{array}$ & & & \\
\hline Post * Ownership Difference & & & & & & & & & & & $\begin{array}{r}0.016 \\
(0.005)\end{array}$ & $* * *$ \\
\hline $\begin{array}{l}\text { Ownership Difference } * \text { Dividend Payer } \\
\text { Indicator }\end{array}$ & & & & & & & & & & & $\begin{array}{r}0.03 \\
(0.008)\end{array}$ & $* * *$ \\
\hline Trend & $\begin{array}{l}0.046 \\
(0.01)\end{array}$ & & $\begin{array}{r}0.08 \\
(0.004)\end{array}$ & & $\begin{array}{r}0.06 \\
(0.003)\end{array}$ & *** & $\begin{array}{r}0.07 \\
(0.007)\end{array}$ & $* * *$ & $\begin{array}{r}0.07 \\
(0.007)\end{array}$ & $* * *$ & $\begin{array}{r}0.07 \\
(0.007)\end{array}$ & $* * *$ \\
\hline Post $*$ Trend & $\begin{array}{r}-0.004 \\
(0.02)\end{array}$ & & $\begin{array}{r}-0.03 \\
(0.012)\end{array}$ & $* * *$ & $\begin{array}{r}-0.04 \\
(0.009)\end{array}$ & **** & $\begin{array}{r}-0.014 \\
(0.02)\end{array}$ & & $\begin{array}{r}-0.009 \\
(0.022)\end{array}$ & & $\begin{array}{r}-0.009 \\
(0.022)\end{array}$ & \\
\hline Firm Level Controls & Yes & & Yes & & Yes & & Yes & & Yes & & Yes & \\
\hline Firm Fixed Effects & Yes & & Yes & & Yes & & Yes & & Yes & & Yes & \\
\hline Number of Observations & 10184 & & 10184 & & 10184 & & 10202 & & 10064 & & 10064 & \\
\hline R-Squared & 0.49 & & 0.78 & & 0.84 & & 0.46 & & 0.46 & & 0.46 & \\
\hline
\end{tabular}


Table 9 Change of Pay Gap Before and After 2003 Tax Cut Conditional on Firm Type

This table shows the results of fixed effects OLS regression of Log (Pay gap) on firm characteristics, a post-tax cut indicator and a trend variable. The dependent variable is Log (Pay gap) at time t. The same set of firm level control variables as in Table 4 is included in the regressions, and they are measured at year $\mathrm{t}-1$. Those variables are not reported to save space. Standard errors are in parentheses and are computed using heteroskedasticity robust standard errors, clustered at the firm level. The $\operatorname{symbol}^{* * * * *}$, and $^{*}$ denote statistical significance at $1 \%, 5 \%$, and $10 \%$ levels, respectively.

\begin{tabular}{|c|c|c|c|c|c|c|c|c|c|c|}
\hline \multirow[b]{2}{*}{ Post Indicator } & \multicolumn{2}{|l|}{ Model 1} & \multicolumn{2}{|c|}{ Model 2} & \multicolumn{2}{|c|}{ Model 3} & \multicolumn{2}{|c|}{ Model 4} & \multicolumn{2}{|l|}{ Model 5} \\
\hline & $\begin{array}{r}-0.08 \\
(0.038)\end{array}$ & ** & $\begin{array}{r}-0.1 \\
(0.04)\end{array}$ & F**** & $\begin{array}{c}-0.11 \\
(0.04)\end{array}$ & **** & $\begin{array}{l}-0.05 \\
(0.03)\end{array}$ & & $\begin{array}{l}-0.04 \\
(0.03)\end{array}$ & \\
\hline Post* Complex & $\begin{array}{r}0.02 \\
(0.008)\end{array}$ & $* *$ & & & & & & & & \\
\hline Post $*$ High-Tech & & & $\begin{array}{r}-0.004 \\
(0.04)\end{array}$ & & & & & & & \\
\hline \multicolumn{11}{|l|}{ Post $*$ High-Risk } \\
\hline Firm & & & & & $\begin{array}{r}0.007 \\
(0.04)\end{array}$ & & & & & \\
\hline Post* Dividend Payer & & & & & & & $\begin{array}{r}0.04 \\
(0.08)\end{array}$ & & & \\
\hline \multicolumn{11}{|c|}{ Post $*$ Strong Governance } \\
\hline Indicator & & & & & & & & & $\begin{array}{r}-0.03 \\
(0.04)\end{array}$ & \\
\hline Complex Indicator & $\begin{array}{r}0.01 \\
(0.03)\end{array}$ & & & & & & & & & \\
\hline High-Tech Indicator & & & $\begin{array}{r}0.06 \\
(0.07)\end{array}$ & & & & & & & \\
\hline \multicolumn{11}{|l|}{ High-Risk Firm } \\
\hline Indicator & & & & & $\begin{array}{r}-0.019 \\
(0.04)\end{array}$ & & & & & \\
\hline \multicolumn{5}{|c|}{ Dividend Payer Indicator } & & & $\begin{array}{r}0.39 \\
(1.02)\end{array}$ & & & \\
\hline \multicolumn{5}{|c|}{ Strong Governance Indicator } & & & & & $\begin{array}{r}-0.1 \\
(0.03)\end{array}$ & \\
\hline Trend & $\begin{array}{r}0.041 \\
(0.008)\end{array}$ & $* * *$ & $\begin{array}{r}0.046 \\
(0.01)\end{array}$ & $* * *$ & $\begin{array}{r}0.046 \\
(0.01)\end{array}$ & $* * *$ & $\begin{array}{r}0.041 \\
(0.007)\end{array}$ & $* * *$ & $\begin{array}{r}0.05 \\
(0.006)\end{array}$ & $* * *$ \\
\hline Post*Trend & $\begin{array}{r}-0.003 \\
(0.02)\end{array}$ & & $\begin{array}{r}-0.004 \\
(0.02)\end{array}$ & & $\begin{array}{r}-0.003 \\
(0.02)\end{array}$ & & $\begin{array}{r}-0.003 \\
(0.02)\end{array}$ & & $\begin{array}{l}0.002 \\
(0.02)\end{array}$ & \\
\hline Firm Level Controls & Yes & & Yes & & Yes & & Yes & & Yes & \\
\hline $\begin{array}{l}\text { Firm Fixed Effects } \\
\text { Number of }\end{array}$ & Yes & & Yes & & Yes & & Yes & & Yes & \\
\hline Observations & 10184 & & 10184 & & 10184 & & 10184 & & 10184 & \\
\hline R-Squared & 0.47 & & 0.47 & & 0.47 & & 0.47 & & 0.47 & \\
\hline
\end{tabular}


Table 10 Pay gap and Firm Performance Before and After 2003 Tax Cut

This table reports the fixed effects OLS regression of firm value on Log (pay gap) and other firm characteristics, and compare the effect of log (pay gap) on firm value before and after 2003 tax cut, conditional on firm type. The one-year adjusted Tobin's $Q$ is measured at the end of year $t+1$, and the three-year adjusted Tobin's $Q$ is the average adjusted Tobin's $Q$ from time $t+1$ to $t+3$. All independent variables are measured at the end of year $t$. The same set of firm level control variables as in Table 5 is included in the regressions, although they are not reported in order to save space. Standard errors are in parentheses and are computed using heteroskedasticity robust standard errors, clustered at the firm level. The symbol ${ }^{* * * * *},{ }^{*}$, and ${ }^{*}$ denote statistical significance at $1 \%, 5 \%$, and $10 \%$ levels, respectively.

Log (Pay gap)

Log (Pay gap)*Post

Log (Pay Gap)*Complex Firm

Log (Pay Gap)*Complex Firm *Post

Log (Pay gap)* High-Tech Firm

Log (Pay gap)* High-Tech Firm*Post

Firm Level Controls

Firm Fixed Effects

Number of Observations

R-Squared

\begin{tabular}{|c|c|c|c|c|c|c|c|c|c|c|c|}
\hline \multicolumn{2}{|l|}{1} & \multicolumn{2}{|l|}{2} & \multicolumn{2}{|l|}{3} & \multicolumn{2}{|l|}{4} & \multicolumn{2}{|l|}{5} & \multicolumn{2}{|l|}{6} \\
\hline \multicolumn{2}{|l|}{$1 \mathrm{Y}$ Adj. Q } & \multicolumn{2}{|l|}{3 Y Adj.Q } & \multicolumn{2}{|l|}{1 Y Adj. Q } & \multicolumn{2}{|c|}{3 Y Adj.Q } & \multicolumn{2}{|c|}{1 Y Adj. Q } & \multicolumn{2}{|c|}{3 Y Adj.Q } \\
\hline 0.004 & & 0.009 & & -0.006 & & -0.005 & & 0.034 & **** & 0.033 & *** \\
\hline (0.009) & & (0.006) & & $(0.01)$ & & (0.008) & & $(0.011)$ & & (0.008) & \\
\hline \multirow{10}{*}{\multicolumn{2}{|c|}{$\begin{array}{r}-0.03 \\
(0.013)\end{array}$}} & -0.026 & **** & -0.03 & ** & -0.033 & **** & -0.022 & * & -0.016 & * \\
\hline & & $(0.01)$ & & (0.014) & & $(0.01)$ & & (0.013) & & (0.009) & \\
\hline & & & & 0.03 & ** & 0.05 & *** & & & & \\
\hline & & & & (0.014) & & $(0.01)$ & & & & & \\
\hline & & & & 0.003 & & 0.01 & **** & & & & \\
\hline & & & & $(0.004)$ & & (0.002) & & & & & \\
\hline & & & & & & & & -0.06 & **** & -0.05 & **** \\
\hline & & & & & & & & (0.015) & & $(0.01)$ & \\
\hline & & & & & & & & -0.03 & *** & -0.03 & *** \\
\hline & & & & & & & & (0.004) & & $(0.003)$ & \\
\hline
\end{tabular}

\begin{tabular}{rrrrrr} 
Yes & Yes & Yes & Yes & Yes & Yes \\
Yes & Yes & Yes & Yes & Yes & Yes \\
9709 & 9707 & 9707 & 9707 & 9707 & 9707 \\
0.76 & 0.84 & 0.76 & 0.84 & 0.77 & 0.84 \\
\hline
\end{tabular}


Log (Pay gap)

Log (Pay gap)*Post

Log (Pay gap)* High-Risk Firm

Log (Pay gap)* High-Risk Firm*Post

Log (Pay Gap)*Good Governance Firm

Log (Pay Gap)*Good Governance Firm*Post

Firm Level Controls

Firm Fixed Effects

Number of Observations

R-Squared

\begin{tabular}{|c|c|c|c|c|c|c|c|}
\hline \multicolumn{2}{|l|}{7} & \multicolumn{2}{|l|}{8} & \multicolumn{2}{|l|}{9} & \multicolumn{2}{|l|}{10} \\
\hline \multicolumn{2}{|l|}{1 Y Adj. Q } & \multicolumn{2}{|l|}{3 Y Adj.Q } & \multicolumn{2}{|l|}{1 Y Adj. Q } & \multicolumn{2}{|l|}{3 Y Adj.Q } \\
\hline 0.03 & $* *$ & 0.02 & $* *$ & 0.001 & & -0.001 & \\
\hline$(0.014)$ & & $(0.01)$ & & $(0.01)$ & & $(0.01)$ & \\
\hline-0.03 & $* *$ & -0.026 & $* * *$ & -0.005 & & -0.002 & \\
\hline$(0.013)$ & & $(0.01)$ & & $(0.01)$ & & $(0.01)$ & \\
\hline-0.035 & $* *$ & -0.02 & * & & & & \\
\hline$(0.016)$ & & $(0.011)$ & & & & & \\
\hline-0.001 & & -0.01 & $* * *$ & & & & \\
\hline$(0.004)$ & & $(0.002)$ & & & & & \\
\hline & & & & 0.017 & & 0.004 & \\
\hline & & & & (0.014) & & $(0.01)$ & \\
\hline & & & & -0.01 & $* *$ & -0.013 & $* * *$ \\
\hline & & & & $(0.005)$ & & $(0.003)$ & \\
\hline Yes & & Yes & & Yes & & Yes & \\
\hline Yes & & Yes & & Yes & & Yes & \\
\hline 9700 & & 9700 & & 9700 & & 9700 & \\
\hline 0.77 & & 0.84 & & 0.73 & & 0.82 & \\
\hline
\end{tabular}


Table 11 Horizontal Pay Gap and Firm Value

We examine horizontal pay gap in this table. Horizontal pay gap is the dollar difference between the 75th percentile and 25th percentile of the total compensation for all non-CEO executives. Panel A reports the summary statistics of the horizontal pay gap. Panel B reports the regression results of firm 3-year industryadjusted Q on the horizontal pay gap and other control variables. All independent variables are measured at the end of year $t$. The same set of firm level control variables as in Table 5 is included in the regressions, although they are not reported in order to save space. Standard errors are in parentheses and are computed using heteroskedasticity robust standard errors, clustered at the firm level. The symbol $* * *, * *$, and $*$ denote statistical significance at $1 \%, 5 \%$, and $10 \%$ levels, respectively.

Panel A

\begin{tabular}{lccc}
\hline & Mean & Lower Quartile & Median \\
\cline { 2 - 4 } Horizontal Pay Gap (000\$) & 872.27 & 166.14 & 392.96 \\
Log (Horizontal Pay Gap) & 5.96 & 5.11 & 5.97 \\
\hline \hline
\end{tabular}

Panel B

\begin{tabular}{|c|c|c|c|c|c|c|c|c|}
\hline & 1 & 2 & 3 & 4 & \multicolumn{2}{|l|}{5} & \multicolumn{2}{|l|}{6} \\
\hline & 3 Y Adj.Q & 3 Y Adj.Q & 3 Y Adj.Q & 3 Y Adj.Q & \multicolumn{2}{|l|}{3 Y Adj.Q } & \multicolumn{2}{|c|}{3 Y Adj.Q } \\
\hline Log (Horizontal Pay Dispersion) & $\begin{array}{c}0.02 \\
(0.005)\end{array}$ & $\begin{array}{r}-0.001 \\
(0.007)\end{array}$ & $\begin{array}{c}0.021 \\
(0.005)\end{array}$ & $\begin{array}{r}0.06 \\
(0.03)\end{array}$ & $\begin{array}{r}0.03 \\
(0.006)\end{array}$ & & \multicolumn{2}{|l|}{$\begin{array}{r}0.075 \\
(0.012)\end{array}$} \\
\hline \multicolumn{2}{|l|}{ Log (Horizontal Pay Dispersion)* Complex Firm } & $\begin{array}{r}0.0015 \\
(0.01)\end{array}$ & & & & & & \\
\hline \multicolumn{2}{|c|}{ Log (Horizontal Pay Dispersion)* Corporate Governance Index } & & $\begin{array}{r}-0.001 \\
(0.001)\end{array}$ & & & & & \\
\hline \multicolumn{2}{|c|}{ Log (Horizontal Pay Dispersion)* Non-CEO Equity Delta } & & & $\begin{array}{r}-0.004 \\
(0.003)\end{array}$ & $\begin{array}{r}-0.27 \\
(0.07)\end{array}$ & & & \\
\hline \multicolumn{9}{|l|}{ Log (Horizontal Pay Dispersion)* R\&D/TA } \\
\hline \multicolumn{3}{|c|}{ Log (Horizontal Pay Dispersion)* Volatility of Stock Return } & & & & & $\begin{array}{r}-0.39 \\
(0.07)\end{array}$ & $* * *$ \\
\hline Firm Level Controls & Yes & Yes & Yes & Yes & Yes & & Yes & \\
\hline Firm Fixed Effects & Yes & Yes & Yes & Yes & Yes & & Yes & \\
\hline Year Fixed Effects & Yes & Yes & Yes & Yes & Yes & & Yes & \\
\hline Number of Observations & 9709 & 9709 & 9709 & 9713 & 9713 & & 9700 & \\
\hline R-Squared & 0.84 & 0.84 & 0.84 & 0.84 & 0.84 & & 0.84 & \\
\hline
\end{tabular}


Table 12 IV-GMM Estimation of the Effect of Pay Gap on Firm Value

This table reports the GMM estimation of the relationship between pay gap and firm value (three-year adjusted Q) based on firm characteristics, using instrumental variables. The exogenous instruments for the pay gap are the industry median pay gap and the number of internal CEO succession in an industry for every sample year. The instrumental variables for the interactions of pay gap and different firm characteristics are the interactions of the each of the two exogenous variables with the same set of firm characteristics. Standard errors are in parentheses and are computed using heteroskedasticity robust standard errors, clustered at the firm level. The symbol ${ }^{* * *},{ }^{* *}$, and ${ }^{*}$ denote statistical significance at $1 \%, 5 \%$, and $10 \%$ levels, respectively.

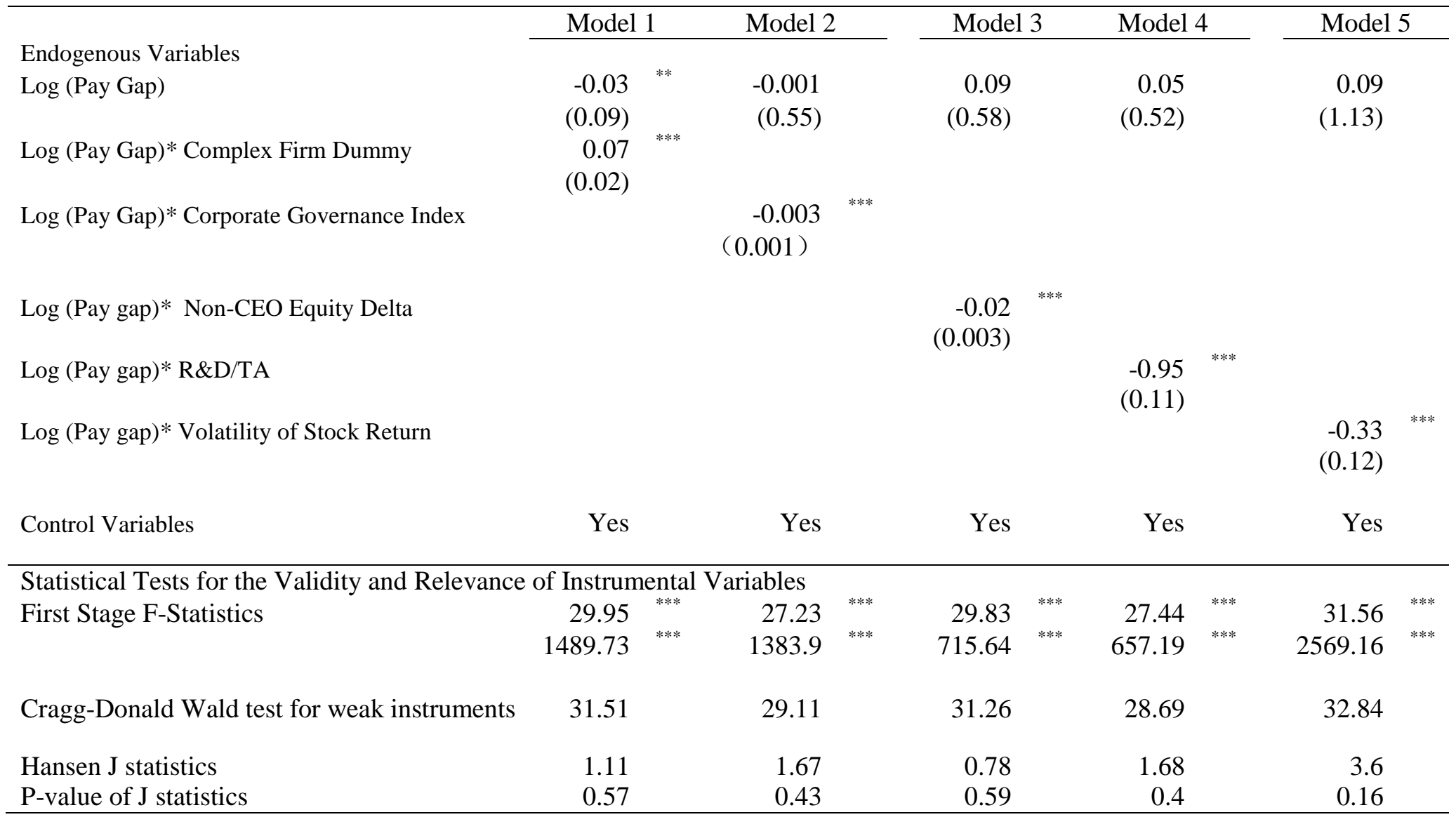

